https://doi.org/10.11646/zootaxa.4526.1.1

http://zoobank.org/urn:lsid:zoobank.org:pub:028FC5EA-7123-4F3A-B6C4-5EBE57ADBE23

\title{
Deep-sea ascidians (Chordata, Tunicata) from the SW Atlantic: species richness with descriptions of two new species
}

\author{
TAMARA MAGGIONI ${ }^{1,2,3}$, ANABELA TAVERNA ${ }^{1,2}$, PAOLA B. REYNA ${ }^{1,2}$, GASTÓN ALURRALDE ${ }^{1,2}$, \\ CLARA RIMONDINO ${ }^{1,2} \&$ MARCOS TATIÁN ${ }^{1,2}$ \\ ${ }^{1}$ Universidad Nacional de Córdoba, Facultad de Ciencias Exactas, Físicas y Naturales, Ecología Marina, Córdoba, Argentina. \\ ${ }^{2}$ Consejo Nacional de Investigaciones Científicas y Técnicas (CONICET), Instituto de Diversidady Ecología Animal (IDEA), Córdoba, \\ Argentina. \\ ${ }^{3}$ Corresponing author. E-mail: tamaramaggioni@gmail.com
}

\begin{abstract}
The understudied deep-sea benthic communities from the Southwestern Atlantic continental slope (200 m-3000 m depth) were sampled on August 2012 in an area located around $38^{\circ} \mathrm{S}$ that included the Mar del Plata submarine canyon. In these samplings we found a total of 16 ascidian species from six different families, of which two corresponded to new species. These were: Aplidium meridianum (Sluiter, 1906); Aplidium variabile (Herdman, 1886); Aplidium marplatensis Maggioni \& Tatián (sp. nov. present work); Aplidium solitarium Maggioni \& Tatián (sp. nov. present work); Synoicum georgianum Sluiter, 1932; Synoicum molle (Herdman, 1886); Synoicum sp.; Polysyncraton trivolutum (Millar, 1960); Sycozoa umbellata (Michaelsen, 1898); Ascidia meridionalis Herdman, 1880; Cnemidocarpa drygalskii (Hartmeyer, 1911); Styela squamosa Herdman, 1881; Pyura pilosa Monniot C. \& Monniot F., 1974; Molgula pyriformis Herdman, 1881; Molgula setigera Ärnbäck-Christie-Linde, 1938 and Asajirus indicus (Oka, 1913). Based on morphological evidence, we propose the new synonymy: Molgula setigera Ärnbäck-Christie-Linde, $1938=$ Molgula marioni Millar, $1960=$ Molgula robini Monniot C. \& Monniot F., 1983. We also propose to maintain Molgula pyriformis and Molgula malvinensis as separate species. We report: the extension of the distribution range of Aplidium meridianum, Synoicum georgianum, Polysyncraton trivolutum, Sycozoa umbellata, Cnemidocarpa drygalskii, Pyura pilosa and Molgula setigera, being the first time they are collected off La Plata River; the deepest registers for Synoicum georgianum, Poylsyncraton trivolutum, Sycozoa umbellata, Ascidia meridionalis, Pyura pilosa, Molgula pyriformis and Molgula setigera; and the shallowest register for Synoicum molle.
\end{abstract}

Key words: Ascidiacea, taxonomy, Argentinean continental slope, Aplidium

\section{Resumen}

Las comunidades marinas bentónicas escasamente estudiadas del talud continental del Océano Atlántico Sudoccidental (200 m-3000 m de profundidad) fueron muestreadas en Agosto de 2012, en un área ubicada alrededor de $38^{\circ} \mathrm{S}$ que incluyó el cañón submarino de Mar del Plata. Encontramos un total de 16 especies de ascidias pertenecientes a seis familias diferentes, de las cuales dos correspondieron a especies nuevas. Éstas fueron: Aplidium meridianum (Sluiter, 1906); Aplidium variabile (Herdman, 1886); Aplidium marplatensis Maggioni \& Tatián (sp. nov. este trabajo); Aplidium solitarium Maggioni \& Tatián (sp. nov. este trabajo); Synoicum georgianum Sluiter, 1932; Synoicum molle (Herdman, 1886); Synoicum sp.; Polysyncraton trivolutum (Millar, 1960); Sycozoa umbellata (Michaelsen, 1898); Ascidia meridionalis Herdman, 1880; Cnemidocarpa drygalskii (Hartmeyer, 1911); Styela squamosa Herdman, 1881; Pyura pilosa Monniot C. \& Monniot F., 1974; Molgula pyriformis Herdman, 1881; Molgula setigera Ärnbäck-Christie-Linde, 1938 y Asajirus indicus (Oka, 1913). Basados en evidencia morfológica, proponemos la siguiente nueva sinonimia: Molgula setigera ÄrnbäckChristie-Linde, 1938 = Molgula marioni Millar, 1960 = Molgula robini Monniot C. \& Monniot F., 1983. También proponemos mantener Molgula pyriformis y Molgula malviniensis como entidades específicas separadas. En este trabajo reportamos: la ampliación del rango de distribución de Aplidium meridianum, Synoicum georgianum, Polysyncraton trivolutum, Sycozoa umbellata, Cnemidocarpa drygalskii, Pyura pilosa y Molgula setigera, siendo la primera vez que se recolectan mar afuera de la desembocadura del Río de La Plata; los registros de mayor profundidad de Synoicum geor- 
gianum, Poylsyncraton trivolutum, Sycozoa umbellata, Ascidia meridionalis, Pyura pilosa, Molgula pyriformis y Molgula setigera; y el registro de menor profundidad de Synoicum molle.

Palabras clave: Ascidiacea, taxonomía, talud continental argentino, Aplidium

\section{Introduction}

The deep-sea is the most understudied environment on Earth (Woolley et al. 2016), in spite of encompassing roughly $90 \%$ of the oceans and holding extremely important assemblages and biological diversity (Hessler \& Sanders 1967; Sanders 1968; Rex 1981; Grassle 1991; Ramírez-Llodra \& Billet 2006; Loreau 2007; Ebbe et al. 2010; Ramírez-Llodra et al. 2010). The latter authors reported a total of 22 new deep-sea habitats encountered in the past 170 years, with an exponential rate of discovery that has intensified in the last 30 years. Among these, deep continental margins (150 to $3500 \mathrm{~m}$ depth) account for approximately $11 \%$ of the ocean floor (Levin \& Sibuet 2012), representing the second most extensive deep-sea habitat after the deep seafloor (75\% coverage). Despite this, the proportion of its assessment has been minimal (Menot et al. 2010). Canyons, with an estimated total length of $25000 \mathrm{~km}^{2}$, also present a minimal percentage area investigated (Ramírez-Llodra et al. 2010). The Argentinean deep continental margin (SW Atlantic), encompassing from approximately $35^{\circ} \mathrm{S}$ to $55^{\circ} \mathrm{S}$ (Piola \& Rivas 1997 ), is the largest margin in the Southern Hemisphere (Priotto 2017), with an extension of $2 \times 10^{6} \mathrm{~km}^{2}$ (Violante et al. 2010). Notwithstanding, just six expeditions have circumnavigated and sampled only parts of the area at those depths: the British Challenger Expedition (1872-1876) (one station); the British Discovery (1926-1938) (14 stations); the U.S. Eltanin cruises (1962-1965) (three stations); the U.S. Atlantis II 60 ${ }^{\text {th }}$ campaign (1971) (14 stations); the Russian's Academic Kurchatov cruise 11 (1971-1972) (one station) and the Dimitry Mendeleev cruise 43 (1989) (one station).

Ascidians (Chordata, Tunicata) are important but often understudied members of macrobenthic communities (Lagger \& Tatián 2013), especially in the deep-sea. Among other deep invertebrate marine taxa, ascidians show their maximum richness at greater depths (Monniot \& Monniot 1978). Despite this, taxonomic works on deep-sea ascidians from the Argentine Basin are scarce, fragmented and out of date (Herdman 1886; Kott 1969; Monniot \& Monniot 1976; Monniot \& Monniot 1985; Sanamyan \& Sanamyan 2002). In the last 41 years, only two new deepsea ascidian species have been reported for the area: Minipera tacita Monniot C. \& Monniot F., 1985 and Culeolus likae Sanamyan K.E. \& Sanamyan N.P., 2002. Taverna et al. (2018) recently presented the most updated ascidian species compilation for the SW Atlantic and SE Pacific. However, the records provided only account for shallower water species $(0-500 \mathrm{~m})$.

In 2012 Argentina initiated its first series of deep-sea exploratory campaigns: the Continental Slope Campaigns. Efforts were directed towards the assessment of an area rich in nutrients provided by the effluents of the La Plata River and the upwelling of the cold Malvinas Current. It is also a Frontal Zone between the latter and the Brazil Current (Pereira-Brandini et al. 2000; Carreto et al. 2007; Muñoz et al. 2012). In regard to the ascidian fauna, the selected area had only been sampled three times. The Challenger Expedition (1872-1876), at Station 320 , collected a total of ten ascidian species, all of them new to science (Herdman 1886). In the 1960's, the North American Atlantis II $60^{\text {th }}$ Campaign recovered 22 ascidian species, of which seven were reported new (Monniot \& Monniot 1976; 1985). Finally, in 1989 the Russian 43 ${ }^{\text {th }}$ Expedition on-board the RV Dimitry Mendeleev (Station 4109) collected three species, one of them new (Sanamyan \& Sanamyan 2002). But the area not only has the potential of revealing new taxa: the taxonomical status of ten ascidian species already collected from the site lacks a proper description and thus, requires a revision.

In the present work we report the ascidian fauna findings of the Argentinian 2012 Continental Slope Campaign. A total of 16 ascidian species were collected along a bathymetric gradient along the continental slope of the SW Atlantic, around $38^{\circ} \mathrm{S}$, including the Mar del Plata submarine canyon. We incorporate a comprehensive list of the species, including two new ones, accompanied with morphological descriptions, detailed taxonomical observations and ecological considerations as a basis for future research. 


\title{
Materials and methods
}

The examined specimens were collected during the first Argentinian Continental Slope Campaigns, onboard the R/ V A.R.A. Puerto Deseado (CONICET, Argentina) within the Argentinian Exclusive Economic Zone, on August 2012. The prospections extended along a bathymetric gradient between 200 and $3000 \mathrm{~m}$ close to $38^{\circ} \mathrm{S}$, including the Mar del Plata submarine canyon (Fig. 1). The total number of samplings ascended to 33. The sampling devices used consisted of a fishing net and two epibenthic trawls (mesh sizes of $3 \times 3 \mathrm{~cm}$ and $1 \times 1 \mathrm{~mm}$ ).

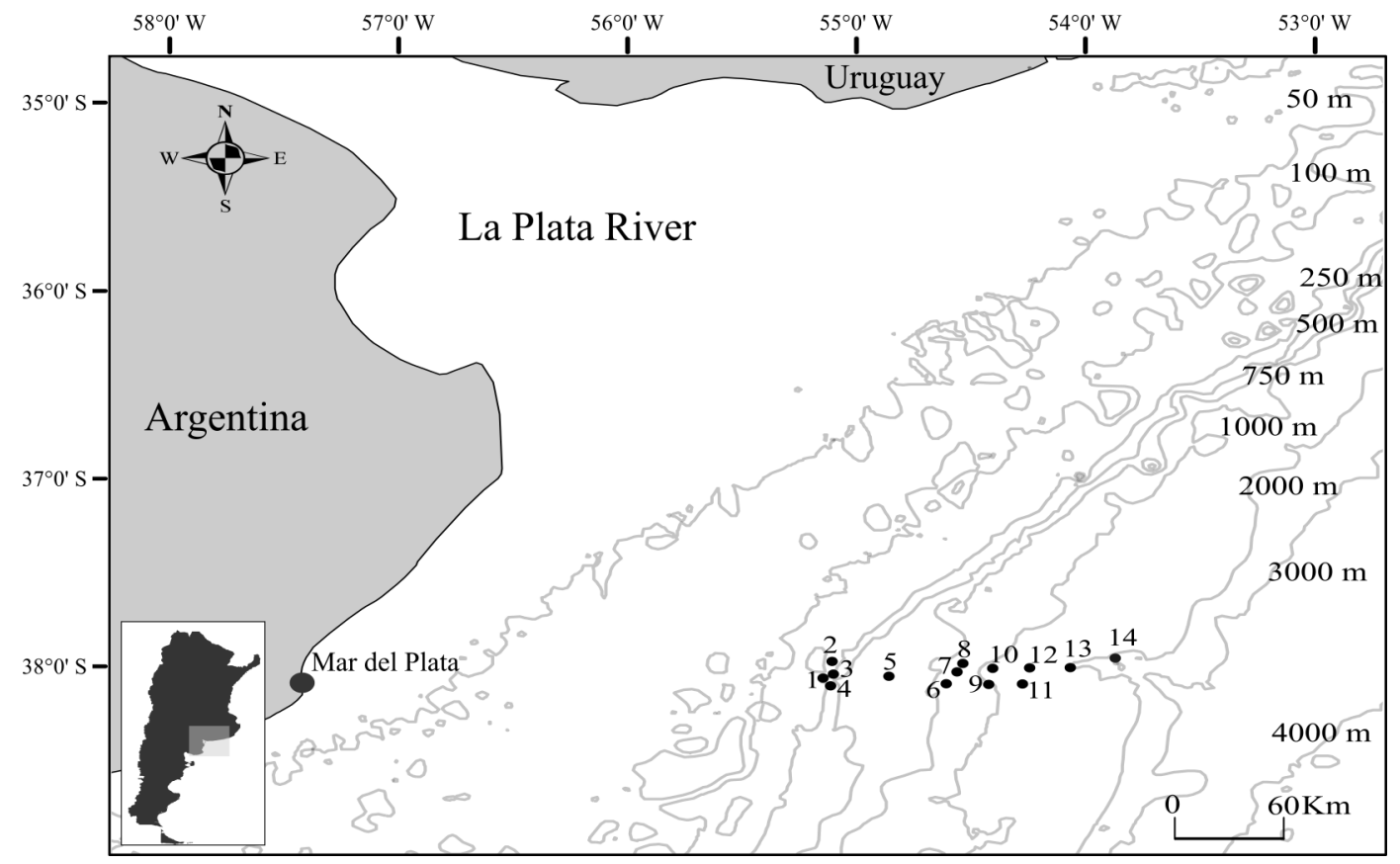

FIGURE 1. Study area with details of the locations where samples were collected (stations 1-14).

Onboard, the specimens were photographed alive, relaxed under seawater with menthol crystals for two hours and fixed in $4 \%$ formalin-seawater. In the laboratory, for colonial ascidians, a minimum of ten zooids per colony were removed and studied under a stereomicroscope. Each zooid was measured and photographed. For solitary specimens, the whole individual was dissected, studied under a stereomicroscope and photographed. All specimens were deposited in the collection of the Museo de Zoología, Universidad Nacional de Córdoba (MZUCVI).

Species recorded. Ascidians were present in $42 \%$ of the prospections (14 out of the 33 samplings performed) (Fig. 1). A total of 16 species were found, of which nine were colonial and seven solitary forms. Two new species are proposed. Eight species were registered for the first time in the study area, expanding their known distribution range. Other seven species extended their known bathymetric range: six with the deepest record and one with the shallowest record (Table 1).

\section{Descriptions}

Order APLOUSOBRANCHIA Lahille, 1886

Family POLYCLINIDAE Milne-Edwards, 1841

\author{
Genus Aplidium Savigny, 1816
}

\section{Aplidium meridianum (Sluiter, 1906)}

References: Amaroucium meridianum Sluiter, 1906: 15, fig. 12, pl. 1.

Aplidium meridianum Monniot F. 1978: 4, fig. 1A (type revision); Monniot et al. 2011: 12, fig. 6 (synonymy). 
Material examined: 22 colonies; net; -38.0164 lat. -54.5054 long. (station 9); 1006 m; 11 August 2012 (Figure 2).

Colonies are dome-shaped, spherical or digitiform supported by small, coarse bases with thin, short rhizoids encrusted with mud and grains of sand. The average size of the colonies is $2.3 \mathrm{~cm}$ in diameter and $1.3 \mathrm{~cm}$ tall. The tunic is smooth and free of external material. Zooids can be seen through transparency. When alive, the tunic is grayish and the zooids are white (Fig. 2). After conservation in formalin, the tunic turns light gray and the zooids turn pinkish. No regular systems are formed, but some colonies displayed elliptical or longitudinal row patterns. Cloacal apertures are inconspicuous.

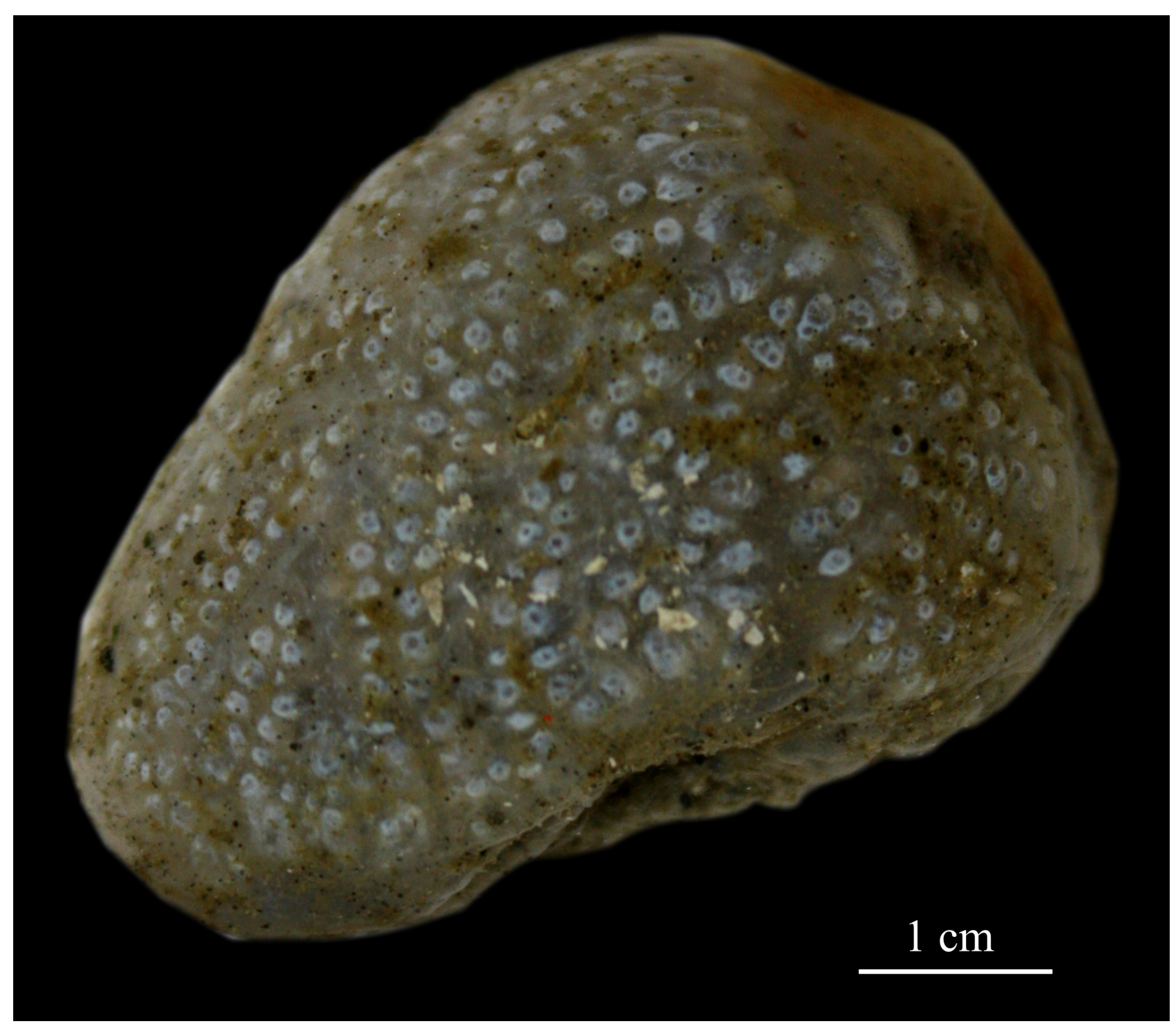

FIGURE 2. Aplidium meridianum (Sluiter, 1906). Colony.

Zooids range from five to $12 \mathrm{~mm}$ in length. However, some of the post-abdomens can reach a maximum extension of $14 \mathrm{~mm}$. The small atrial aperture is surrounded entirely by a short ring of tunic. It is situated next to the first and second row of stigmata. The atrial languet is wide and short. There are eight to ten thin and long oral tentacles disposed in a circle. The thorax bears from 12 to 18 rows of 12 to 14 stigmata. Six to ten thin longitudinal muscles run through each side of the zooid.

The stomach has six to eight longitudinal well-marked folds of different sizes. Some folds are shorter than others or even incomplete. The gut loop curves dorsal and posterior and widens toward its final part. The bilobed anus ends between the sixth and eighth row of stigmata.

The gonads are situated under the gut loop with no space in between. The testes are arranged in a simple longitudinal row or in clusters. The number of male follicles ranged from seven to 14 . The sperm duct ends next to the anus. 
Either one or two larvae were found in the atrial cavities of all zooids in an immature state of development.

Remarks. This is the northernmost record of the species, previously known from Antarctic and Sub-Antarctic areas.

\section{Aplidium variabile (Herdman, 1886)}

References: Amaroucium variabile Herdman 1886: 216, pl. XXIX, fig. 7-12.

Aplidium variabile Millar, 1960: 32, fig. 2B; Monniot \& Monniot 1983: 30 (synonymy); Sanamyan \& Schories 2003: 92, fig. 1B, 2E-F; Lagger et al. 2009: 178, fig. 2C.

Material examined: one colony; net; -37.9942 lat. -55.2175 long. (station 1); 250 m; 10 August 2012.

The only colony found is small and irregular in shape, with half of its side slightly convex and the other half plane. It measures $1.8 \mathrm{~cm}$ long by one $\mathrm{cm}$ wide and $0.4 \mathrm{~cm}$ thick. The tunic is smooth and transparent. Zooids are orange when alive and dull yellow after fixation in formalin. They are arranged parallel to each other.

Zooids reach an average of $2.5 \mathrm{~mm}$ in length, with the post-abdomen comparatively shorter than most Polyclinidae (from 0.8 to $1.6 \mathrm{~mm}$ ). However, this feature might be related to the state of sexual maturation of the present colony. The small atrial aperture is located at the level of the third, fourth or fifth row of stigmata. The atrial languet is simple, short and triangular.

There are ten to 12 thin longitudinal muscles on each side of the zooid. The thorax bears 12 rows of stigmata. Each half row contains from 12 to 16 stigmata.

The stomach has from 12 to 14 well-marked folds. The middle intestine forms a middle-sized posterior swelling. The border of the anus is smooth and it can end at the level of the ninth, tenth or eleventh row of stigmata.

All zooids showed scarcely developed gonads. No larvae were found.

Remarks. Aplidium variabile is a common eurybathic species collected from 20 down to $1097 \mathrm{~m}$ depth (Herdman 1886). Its known range of distribution is Circum Sub-Antarctic, with the majority of its records around the Magellan Strait. This is the second record for the type locality (off Mar del Plata, Argentine Sea), since its discovery during the Challenger expedition.

\section{Aplidium marplatensis Maggioni \& Tatián (sp. nov. present work)}

Material examined: one colony; net; -37.9942 lat. -55.2175 long. (station 1); $250 \mathrm{~m} ; 10$ August 2012 (Figures $3 \mathrm{~A}-\mathrm{C})$.

Holotype: MZUCVI0193.

Etymology: in reference to the Mar del Plata submarine canyon, the geographic location where the species was collected.

The colony consists of an ovoid mass, attached to the substrate by a small area with rhizoids. It measures 4.6 $\mathrm{cm}$ in diameter by five $\mathrm{cm}$ in height. The tunic is smooth and free of epibionts or external particles. When alive, the color of the tunic is grayish-brown and the zooids are white (Fig. 3A). After fixation in formalin, the tunic and zooids turn opaque yellow.

Zooids of variable sizes are arranged irregularly around inconspicuous cloacal apertures. The total length varies from $0.3 \mathrm{~cm}$ to $1.4 \mathrm{~cm}$. The thorax and the abdomen are the smallest parts of the body, both being about the same size. The post-abdomen is the longest section of the body, reaching a maximum length of $1.1 \mathrm{~cm}$. The oral aperture has six lobes, although some zooids show a smooth edge. The atrial aperture is wide, leaving almost half of the pharynx exposed. It extends from the second to the sixth row of stigmata and is surrounded by a series of five to six thin and circular fine muscles. The atrial languet is wide, medium sized and trifid.

Thorax and abdomen show six to eight fine longitudinal muscles on each side. The pre-pharyngeal band is thin and circular. The neural ganglion is small and approximately spherical. There are 14 rows of stigmata that contain ten to 12 stigmata per half row.

There is a long and thick esophagus, it widens at its anterior end and narrows when it reaches the stomach. Its course to the stomach may be straight or may present a sharp curve inwards. The stomach is rectangular with rounded edges and presents four to five well marked longitudinal and straight folds. On average, it measures 1.7 
$\mathrm{mm}$ long by $1.1 \mathrm{~mm}$ wide. The intestine also has thick walls. After the stomach, it widens and forms a first pearshaped, sometimes spherical, swelling. Then, it makes a closed turn dorsal and posterior, opening to a second slightly larger swelling. When the ascending branch of the gut loop reaches the level of the stomach, the intestine recovers its initial width and continues its vertical trajectory towards the atrial aperture. The anal border is bilobed and opens at the level of the eighth row of stigmata, just at the lower edge of the atrial aperture.
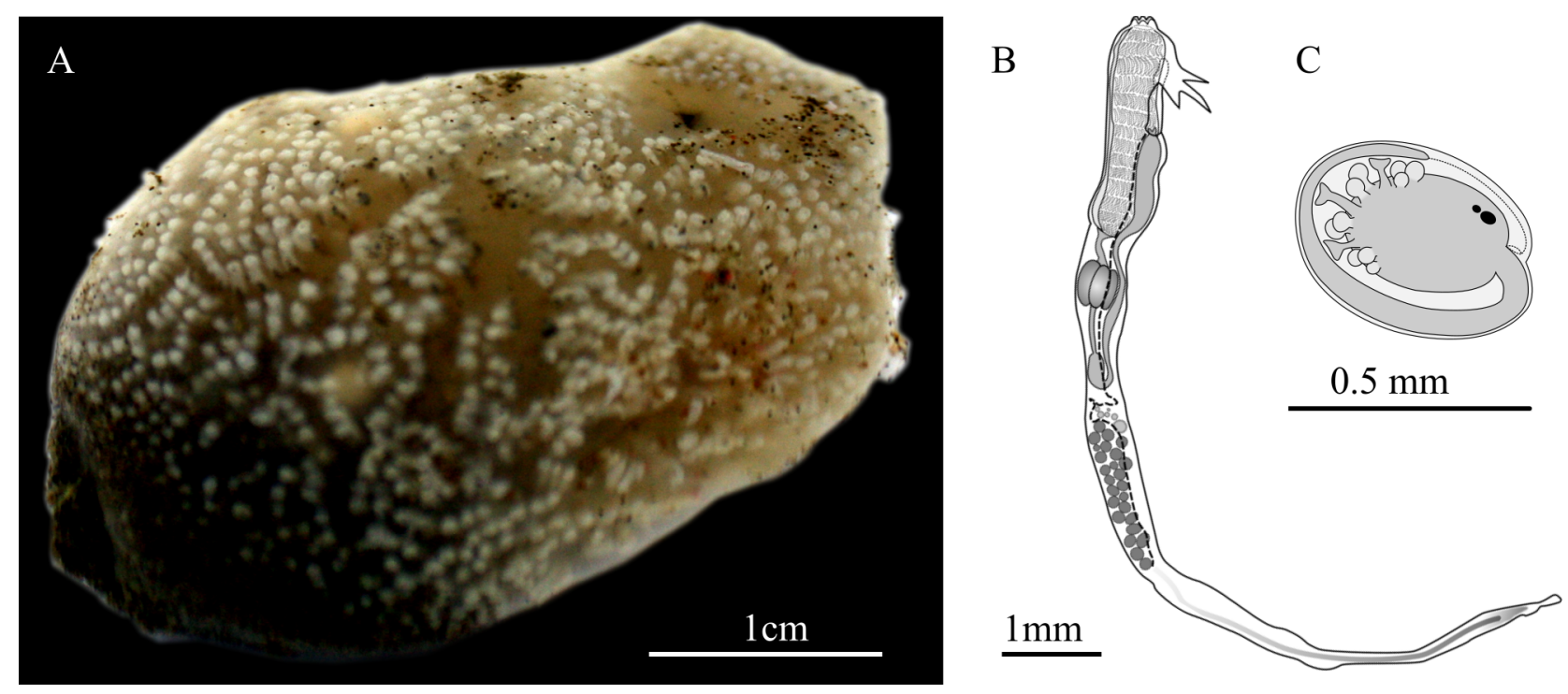

FIGURE 3. Aplidium marplatensis Maggioni \& Tatián (sp. nov. present work). A: colony; B: zooid; C: larva.

In mature zooids, the gonads are located a short distance from the pole of the gut loop. There are four to six rounded and small oocytes, arranged in a semi-spherical ovary at the beginning of the post-abdomen. Directly under the ovary, testes are arranged in longitudinal rows containing 19 to 30 small and spherical follicles that can fill the first half of the length of the post-abdomen. In more mature zooids, testes are arranged in one or two long longitudinal rows. In less mature zooids, with shorter post-abdomens, testicular follicles are smaller and densely packed. The vas deferens bends several times over the ovary; it then turns dorsal and vertical along the abdomen and part of the thorax and ends at the same level as the anus.

The atrial cavity contains one to two developing larvae. The average trunk size of the most mature larvae is one $\mathrm{mm}$ long and $0.6 \mathrm{~mm}$ wide. The larvae have an otolith and an ocellus. There are three adhesive organs arranged in a single line with two anterior ampullae alternating between them and three lateral ampullae on each side, directly adjacent to the most distal adhesive organs. No epidermal vesicles were observed.

Remarks. The genus Aplidium is the most numerous of the Polyclinidae family, with 278 species described to date. This diversity is also found in the deep-sea, with 19 representatives of deep-water Aplidium. However, in the Argentine Basin only 3 deep species of this genus have been recorded. They are: Aplidium effrenatum (Herdman, 1886), Aplidium variabile (Herdman, 1886) and Aplidium falklandicum Millar, 1960. Aplidium effrenatum was described in the $19^{\text {th }}$ century (Herdman 1886) and has not been collected ever since. On the other hand, A. variabile has been collected several times in the Sub-Antarctic area around the tip of South America and Antarctica. Monniot \& Monniot $(1976 ; 1985)$ recorded two additional specimens of Aplidium. However, they could only identify them up to genus level.

The three species of Aplidium cited for the deep waters of the South West Atlantic differ from Aplidium marplatensis Maggioni \& Tatián (sp. nov. present work) mainly due to the presence of a wide atrial aperture. Although the original and unique description of Aplidium effrenatum (Herdman, 1886) is incomplete, it allows to characterize $A$. effrenatum as a different species from the current one. Unlike the colony of $A$. marplatensis Maggioni \& Tatián (sp. nov. present work), the colony of A. effrenatum is thin and encrusting. Its color is described as dull reddish-brown or dark gray-brown. In addition, the tunic was found completely embedded with grains of sand. Finally, the absence of an atrial languet definitively separates A. effrenatum from A. marplatensis Maggioni \& Tatián (sp. nov. present work). 


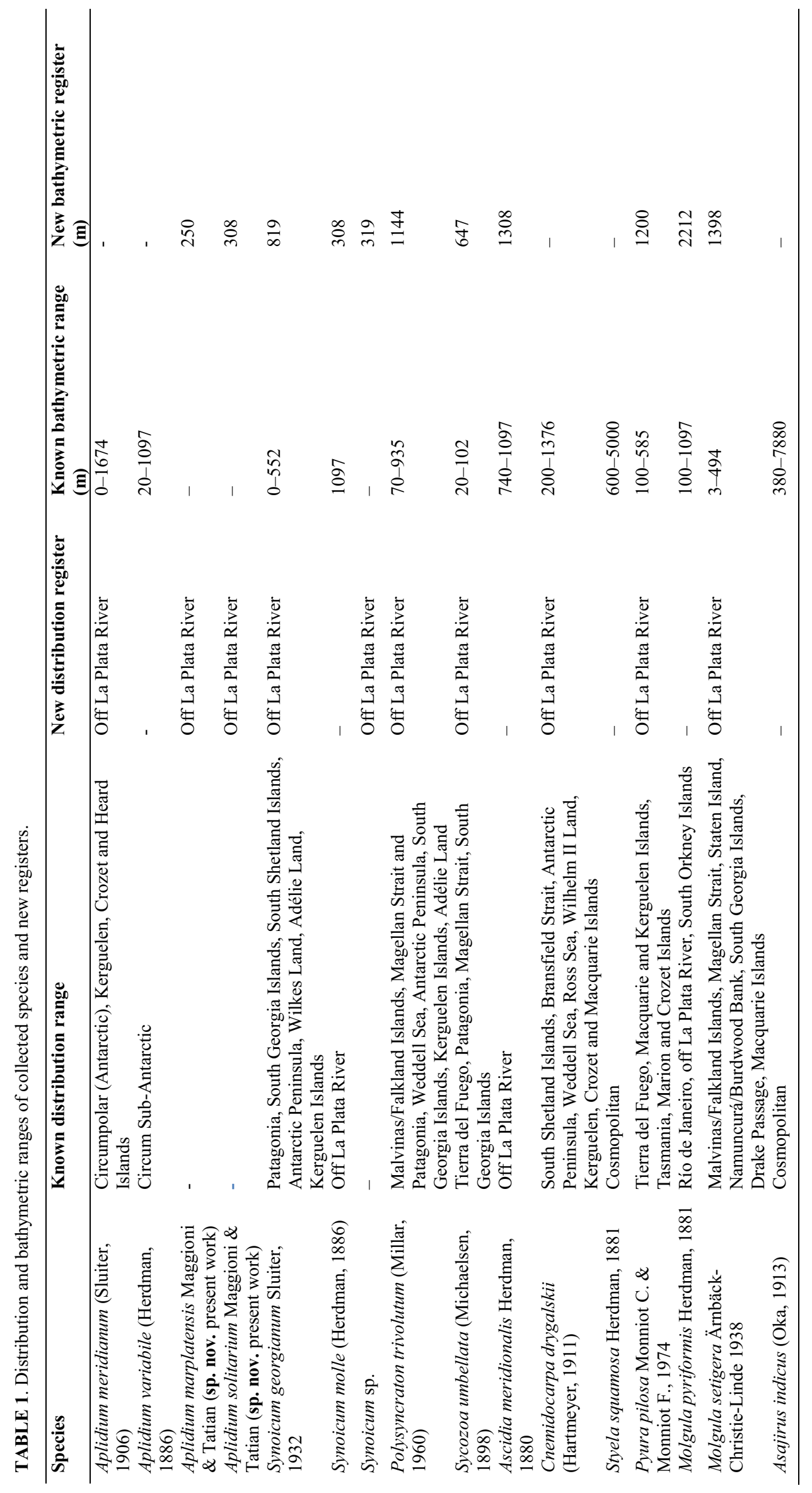




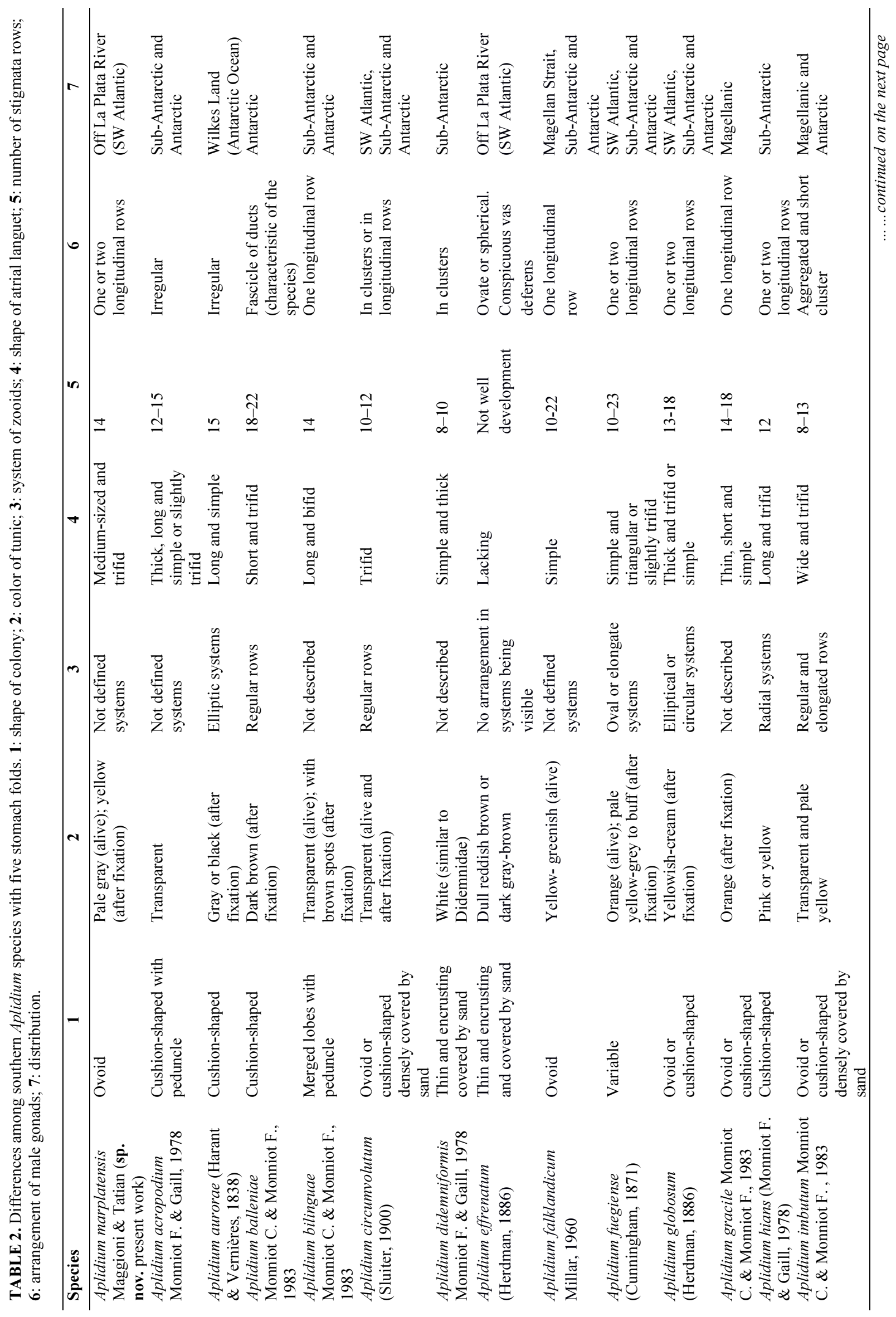




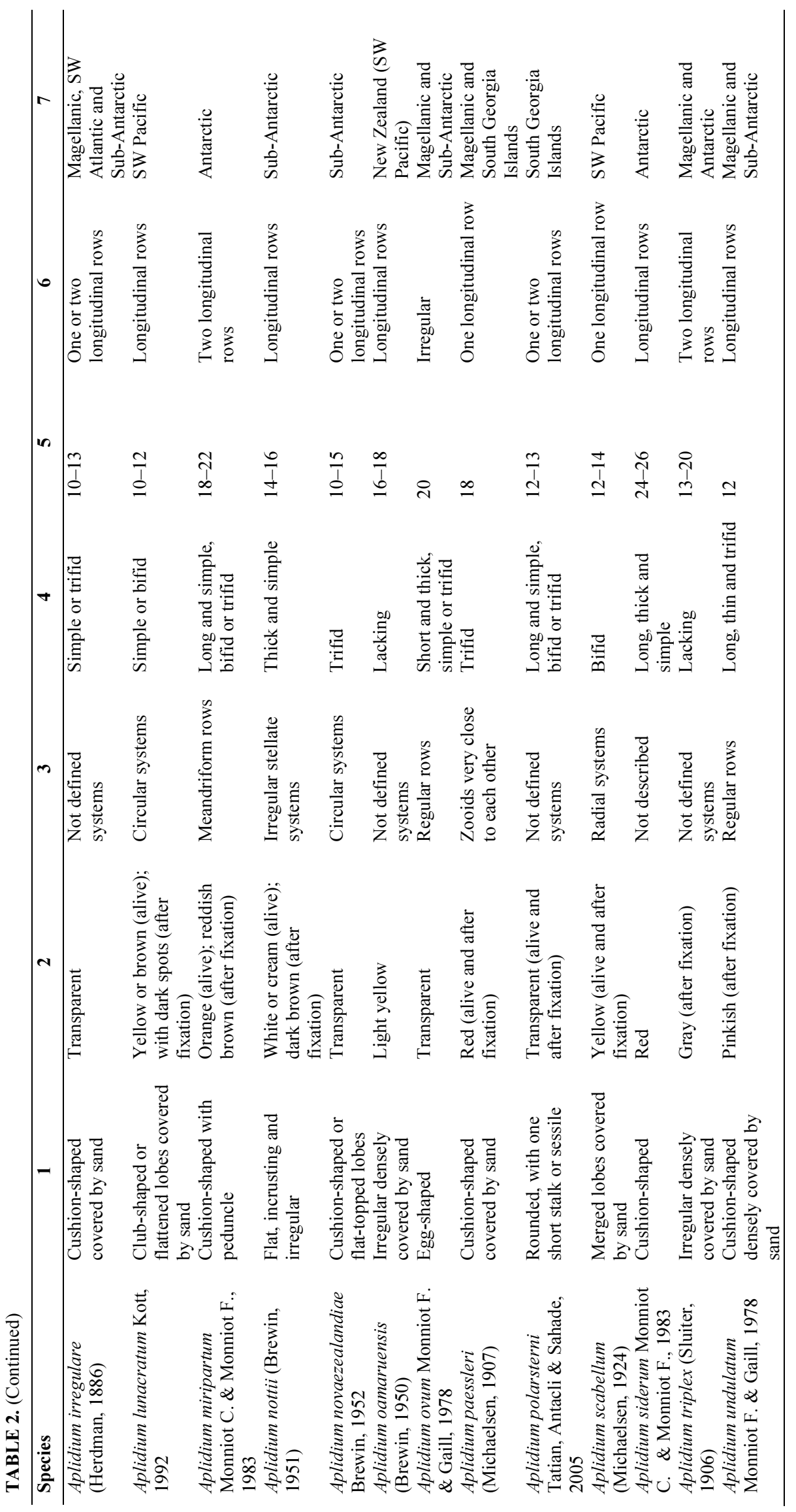


Aplidium variabile (Herdman, 1886) is a well-known Sub-Antarctic species. Unlike A. marplatensis Maggioni \& Tatián (sp. nov. present work), the colony of $A$. variabile is often attached to the substrate through a peduncle. Its color, when alive, is pale yellow. In addition to the length of the atrial aperture, the other character that strongly distinguishes this species from A. marplatensis Maggioni \& Tatián (sp. nov. present work) is the number of stomach folds: while A. variabile shows $12-16$, A. marplatensis Maggioni \& Tatián (sp. nov. present work) presents only five to six.

Aplidium falklandicum Millar, 1960 is similar to Aplidium marplatensis Maggioni \& Tatián (sp. nov. present work) in several general aspects of the colony and the zooid. However, both differ in the following characters: the color of the tunic when alive; the size and position of the atrial aperture; the size and shape of the atrial languet; the position of the anus in relation to the anal border; and the structures present in the larvae. Moreover, the distribution of $A$. falklandicum is restricted to Sub-Antarctic and Antarctic waters.

Aplidium marplatensis Maggioni \& Tatián (sp. nov. present work) clearly belongs to a group of southern Aplidium species characterized by the presence of five stomach folds. This group includes the previously mentioned A. falklandicum and A. effrenatum. It also includes the Antarctic species Aplidium aurorae (Harant \& Vernières, 1938), Aplidium balleniae Monniot C. \& Monniot F., 1983 and Aplidium circumvolutum (Sluiter, 1900), the three of which share with A. marplatensis Maggioni \& Tatián (sp. nov. present work) the presence of a large atrial aperture, a feature not found in any other species of Aplidium (although the zooids of A. balleniae can also show atrial apertures of small or medium size). The differences among these southern five-folded stomach Aplidium species are summarized in Table 2.

\section{Aplidium solitarium Maggioni \& Tatián (sp. nov. present work)}

Material examined: two colonies; net; -37.9783 lat. -55.1983 long. (station 3); 308 m; 17 August 2012 (Figures $4 \mathrm{~A}-\mathrm{C})$.
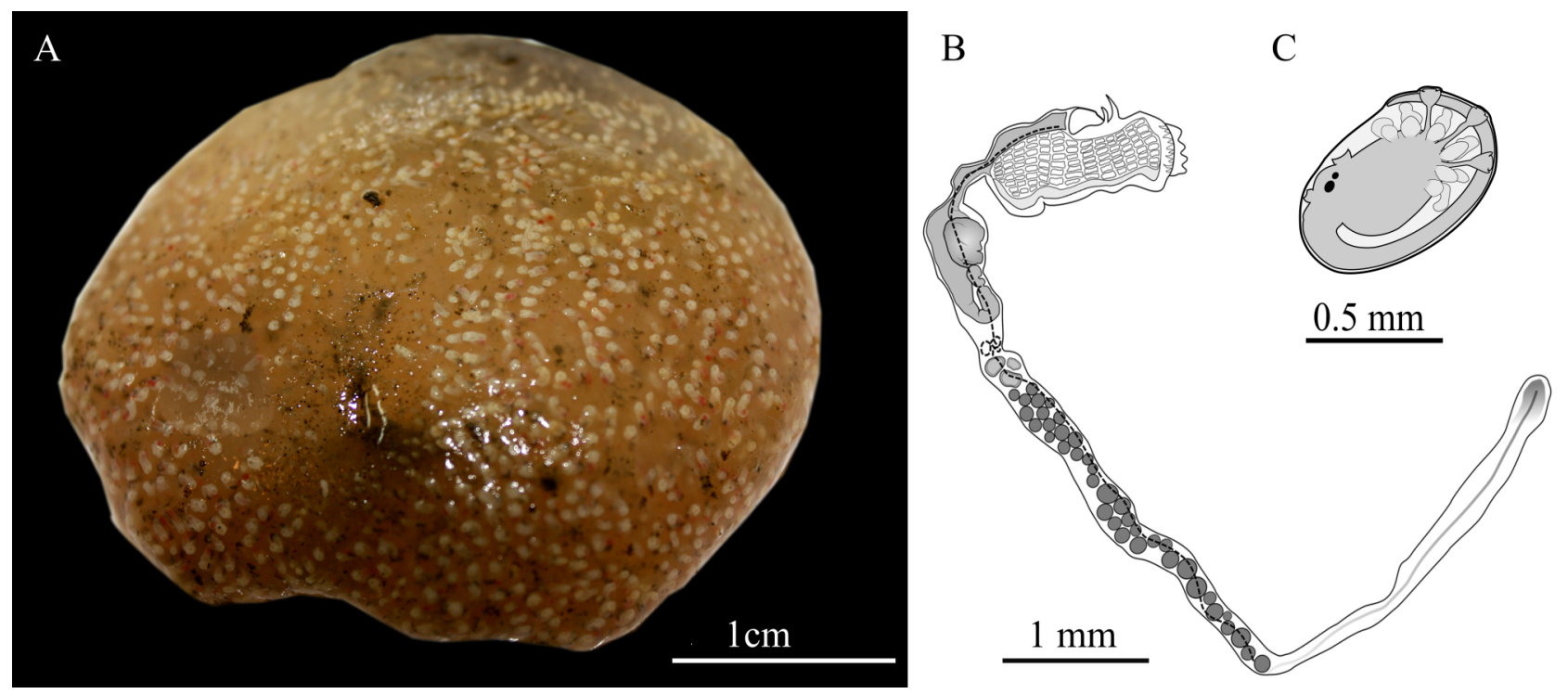

FIGURE 4. Aplidium solitarium Maggioni \& Tatián (sp. nov. present work). A: colony; B: zooid; C: larva.

\section{Holotype: MZUCVI0194.}

Etimology: From solitarium, the latin neuter adjective for solitary or sole, without companion.

The colonies are circular and flattened. They can reach $6.4 \mathrm{~cm}$ in diameter and $1.5 \mathrm{in}$ height. They are attached to the substrate by a small area embedded with grains of sand. The tunic is firm and hard but soft. When alive, the tunic is opaque and amber colored with brownish tones. The zooids are white and exhibit red and orange spots in the oral openings in about half the cases (Fig. 4A). After conservation in formalin the tunic becomes transparent, the zooids turn yellowish and the red and orange spots disappear. Numerous zooids are arranged in irregular elliptical systems around common cloacal apertures.

The thorax is separated from the two posterior regions by a very thin and moderately long constriction. This 
constriction is common in all zooids, but it is more noticeable in the largest zooids of the colony. It is a part of the abdomen. The lengths of the zooids are highly variable, between seven and $23 \mathrm{~mm}$. However, the proportions between regions remain the same. The post-abdomen is the longest and most variable section, depending on the sexual stage of the zooid's maturation. It can be six times longer than the thorax or abdomen, reaching a maximum length of $18 \mathrm{~mm}$. The oral aperture has six well differentiated lobes. The atrial aperture is moderately large, exposing three rows of stigmata. It is located between the fourth and sixth row of stigmata and it is surrounded by a small ring of thin, circular muscles. The atrial languet is very variable in shape: simple; bifid; trifid; and even show four thin, triangular and pointed lobes. More often it is bifid or trifid. The size of the atrial languet is also variable.

The musculature is strong. Approximately 22 longitudinal fibers run through the entire zooid. They are arranged in two well differentiated bands: 12 to 14 muscles are densely grouped over the thickest area of the mantle, while the other eight to ten are evenly distributed over the rest of the zooid, where the mantle becomes thinner. The branchial sac has 13 rows of stigmata. Each half row contains seven thin rectangular stigmata. From ten to 14 oral tentacles are arranged in a circular ring, alternating in sizes. The pre-pharyngeal band is thin, circular and presents soft undulations.

Due to the presence of a constriction between the thorax and the abdomen, the esophagus is particularly narrow and long. It connects vertically with a moderately large stomach. The stomach shows four different types of morphologies: cylindrical, cubic, spherical and pyramidal. The wall of the stomach contains five to six folds, although some zooids showed smooth walls. The intestine has thick walls, it is wide and long. It forms a mediumsized swelling shortly after the end of the stomach. The swelling can be elliptical, almost spherical, cylindrical or rectangular. The intestine turns dorsal and anterior and runs parallel to the stomach until reaching the constriction. This portion of the intestine is the widest, sometimes even more than the stomach, and may have smooth transverse folds. In the constriction, the intestine becomes as narrow and thin-walled as the esophagus. It maintains these characteristics until reaching the lower border of the atrial opening. The anal border is bilobed, showing two marked projections.

The ovary presents from a single large oocyte up to four small rounded oocytes located a few millimeters from the pole of the gut loop. The testes are composed of small and spherical follicles distributed in four, but more frequently, three longitudinal rows. The broad vas deferens ends at the lower border of the atrial aperture, next to the border of the anus.

The atrial cavity of many zooids contains between one to three developing larvae, although the most frequent number is three. The larval dimensions of the trunk reach $1.1 \mathrm{~mm}$ in length and $0.7 \mathrm{~mm}$ wide. The larvae show three adhesive organs arranged in a straight line. Between these adhesive organs and immediately adjacent to the two most distal ones, there are four rows of three ampoullae each. Externally, there are two additional rows of two ampoullae on each side. No epidermal vesicles were observed. The tail surrounds approximately $5 / 8$ of the larval trunk. They present an otolith and an ocellus.

Remarks. The shape and texture of the stomach wall are valid characters for classification among Polyclinidae genera (Millar 1960; Kott 1990). The stomach of the present species shows a diversity of both shape and texture (smooth and with folds). Millar (1960) is the only author who described a species of the genus Aplidium of SubAntarctic (Malvinas/Falkland Islands and Patagonian continental margin) and Antarctic (Graham Land, South Orkney Islands and South Georgia Islands) waters, Aplidium falklandicum Millar, 1960, with a stomach presenting a diversity of shapes and textures. The author states that $A$. falklandicum can show between five to seven slightly marked folds, reduction of folds (which can be discontinued or separated into a few almost imperceptible swellings) and even smooth stomachs. Aplidium falklandicum is similar to Aplidium solitarium Maggioni \& Tatián (sp. nov. present work) in several general aspects of the colony and the zooid, especially regarding the variation of the stomach. However, both differ in the following characters: the number of stigmata rows; the position and extension of the atrial aperture; the shape of the atrial languet; the position of the anus in relation to the atrial aperture; and the disposition of the testes in the post-abdomen. The color of the colonies is also different: specimens of $A$. falklandicum observed and documented alive (Tatián pers. obs.) exhibit a very characteristic greenish-yellow (lemon) color.

The presence of a thinning of the body separates some genera of Polyclinidae. However, this feature had only been reported between the abdomen and the post-abdomen, never before between the thorax and the rest of the body (abdomen and post-abdomen). The presence of a thin neck separating the thorax from the rest of the body was found in all zooids of both examined colonies and cannot be interpreted as an artifact of preservation. More samples will allow to confirm the value of this feature in species diagnosis. 


\section{Genus Synoicum Phipps, 1774}

\section{Synoicum georgianum Sluiter, 1932}

References: Synoicum georgianum Sluiter 1932: 11, fig. 9-10; Monniot \& Monniot 1983: 32 (synonymy); Sanamyan \& Sanamyan 2002: 307-308, fig. 1A; Tatián et al. 2005: 209.

Material examined: one colony; net; -38.0249 lat. -54.7361 long. (station 6); 819 m; 16 August 2012 (Figure 5).

The only colony found consists of a small rounded head $0.5 \mathrm{~cm}$ high by $0.7 \mathrm{~cm}$ wide with a conical peduncle $0.8 \mathrm{~cm}$ long by $0.5 \mathrm{~cm}$ wide (Fig. 5). The zooids are attached by their posterior abdomens to the peduncle. They are all positioned vertically. The entire colony, head and peduncle, is embedded with sand interiorly. The tunic is smooth and grayish. The peduncle is coarse. Zooids are white when alive and after conservation in formalin. The cloacal apertures are inconspicuous. Some zooids presented post-abdomens extremely reduced or even absent, a characteristic related to the state of sexual maturation of each individual.

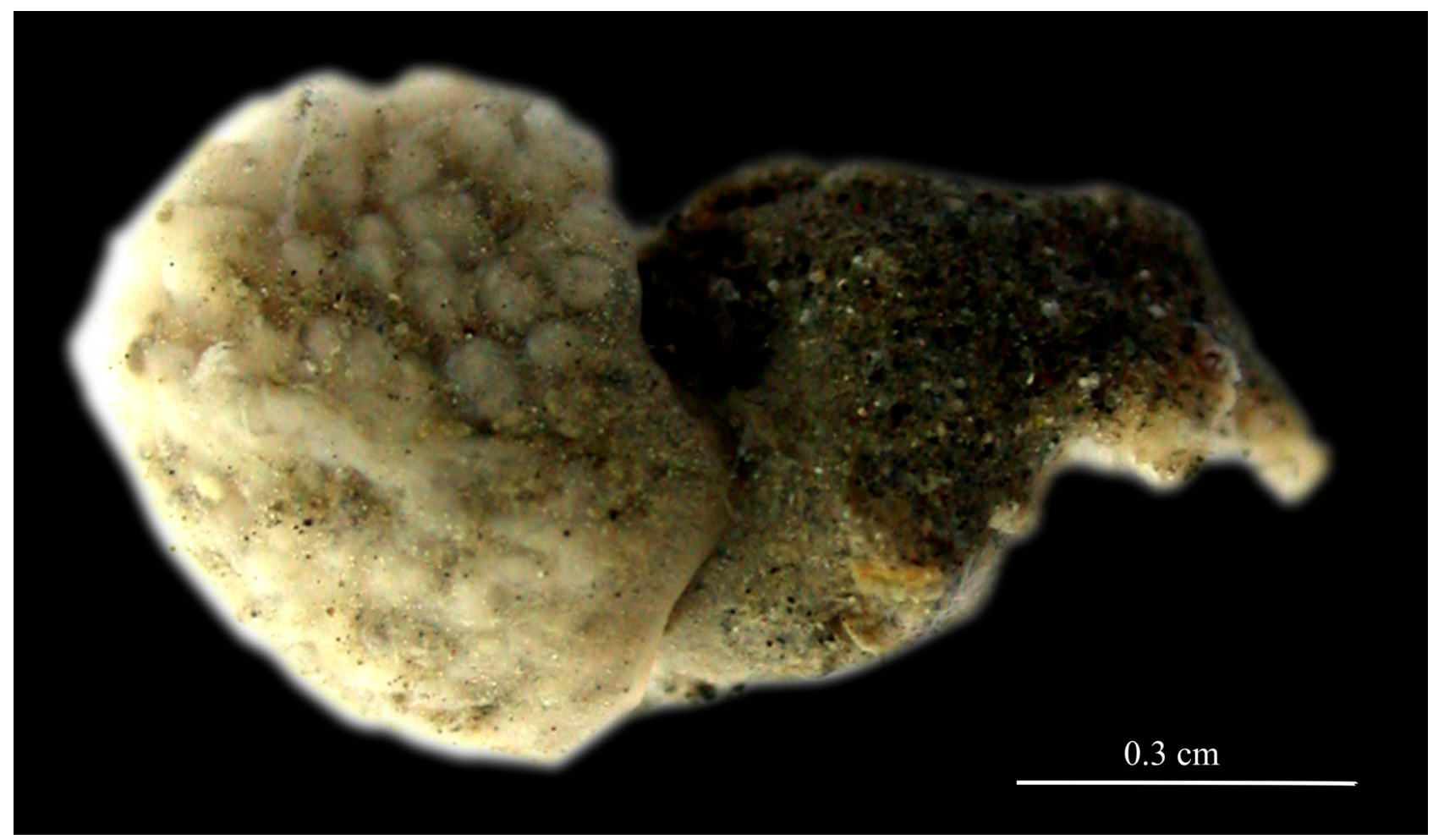

FIGURE 5. Synoicum georgianum Sluiter, 1932.

The oral aperture has six slightly marked lobes. The atrial aperture is moderately big and surrounded by a series of three to four circular muscles. The border of the atrial aperture is smooth. The atrial languet is trifid.

There are from five to nine longitudinal muscles on each side of the zooids. They run vertically through the thorax, abdomen and post-abdomen. Two-sized oral tentacles are distributed alternately in a single circle. The thorax bears from 14 to 16 rows of small rectangular stigmata. Each half row contains from ten to 14 stigmata.

The stomach wall is smooth. The anus is located at the level of the ninth row of stigmata. The posterior margin of the anal border is lobed.

No gonads were found. An immature tailless larva was found in the atrial cavity of one zooid.

Remarks. The colony resembles very closely the Antarctic species Synoicum pererratum (Sluiter, 1932) in several characteristics of the zooids. Both share: the external accumulation of sand, short and stout post-abdomens, the number of longitudinal muscles, and the number of rows of stigmata and stigmata per row. However, they differ in the general shape of the colony, the arrangement of the systems of zooids and in the sizes of zooids. Moreover, both species do not coincide in their location: while $S$. pererratum is confined to the Antarctic region, $S$. georgianum, apart from its Antarctic records, has also been collected from the Patagonian shelf (Millar 1960).

This is the deepest register of the species; the first record below $550 \mathrm{~m}$ (Kott 1969). 


\section{Synoicum molle (Herdman, 1886)}

References: Polyclinum molle Herdman 1886: 194, pl. XXV, figs. 7-9.

Synoycum molle Van Name 1945: 84, fig. 20; Maggioni et al. 2016: 181-185, figs. 2-4.

Material examined: seven colonies; net; -37.9783 lat. -55.1983 long. (station 3); 308 m; 16 August 2012 (Fig. 6).

Colonies are ovoid. They show various sizes, ranging from 2.5 to $9.1 \mathrm{~cm}$ in diameter. The tunic is grayish. When alive, zooids are white. When fixed in formalin, they turn pale yellow. The atrial languet is thin and long, and can be simple or bifid. There are 13 rows of stigmata. Each half row contains ten rectangular stigmata. The stomach wall is smooth and shows two alternate shapes: circular, almost spherical or dome-shaped with a straight base. The anus is bilobed and finishes at the eighth row of stigmata.

Remarks. Until this date, only one colony (the type specimen) had been collected $1097 \mathrm{~m}$ deep (Herdman 1886) few kilometres away from the present study area. Van Name (1945) acknowledged the inadequacy of the original description for a proper species identification. The present material allowed to perform the first exhaustive and complete morphological description of S. molle (see Maggioni et al. 2016).

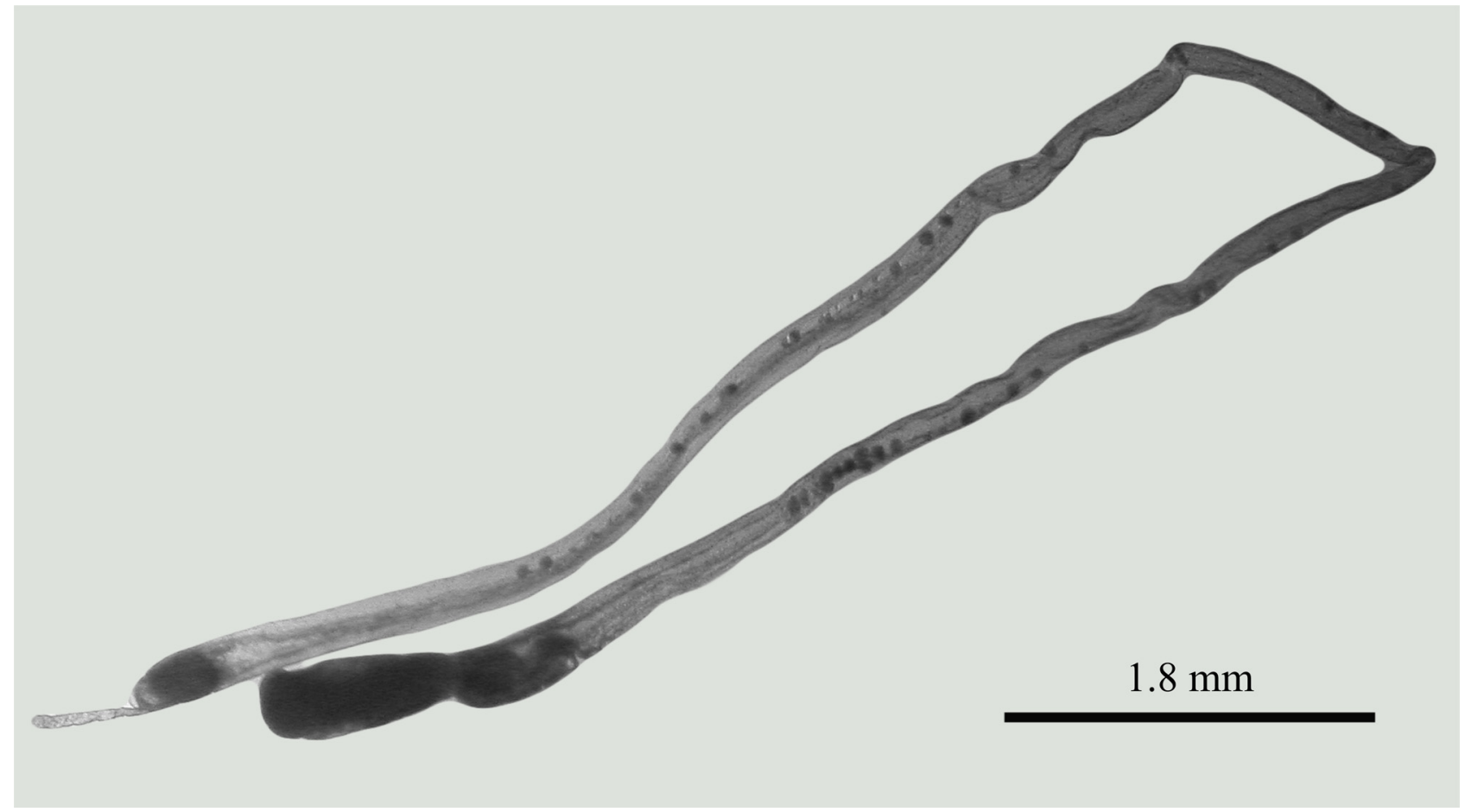

FIGURE 6. Synoicum molle (Herdman, 1886): zooid.

\section{Synoicum sp.}

Material examined: one colony; net; -37.9966 lat. -55.2079 long. (station 4); 319 m; 17 August 2012 (Figure 7).

The colony is almost spherical. It measures two $\mathrm{cm}$ in diameter and $1.8 \mathrm{~cm}$ in height (Fig. 7). Zooids present a short post-abdomen. The oral aperture has six lobes. The atrial aperture is small and simple, and it is located at the upper quarter of the thorax. The atrial languet is simple and short. There is no constriction connecting the abdomen and the post-abdomen. There are eight rows of stigmata. The stomach is rounded and its walls are smooth. The gut loop is simple.

Numerous underdeveloped tailless larvae were found in the atrial cavities of some zooids. There was evidence of strobilation, a characteristic asexual type of reproduction in most Polyclinidae members.

Remarks. Due to the poor state of conservation and stage of sexual maturation of the zooids, the colony was characterized up to genus level. No reliable indicators of species status could be distinguished. The absence of a constriction between the thorax and abdomen, in combination with the presence of a rounded and smooth-walled stomach and a simple gut-loop, enabled us to classify the present specimen as Synoicum. 


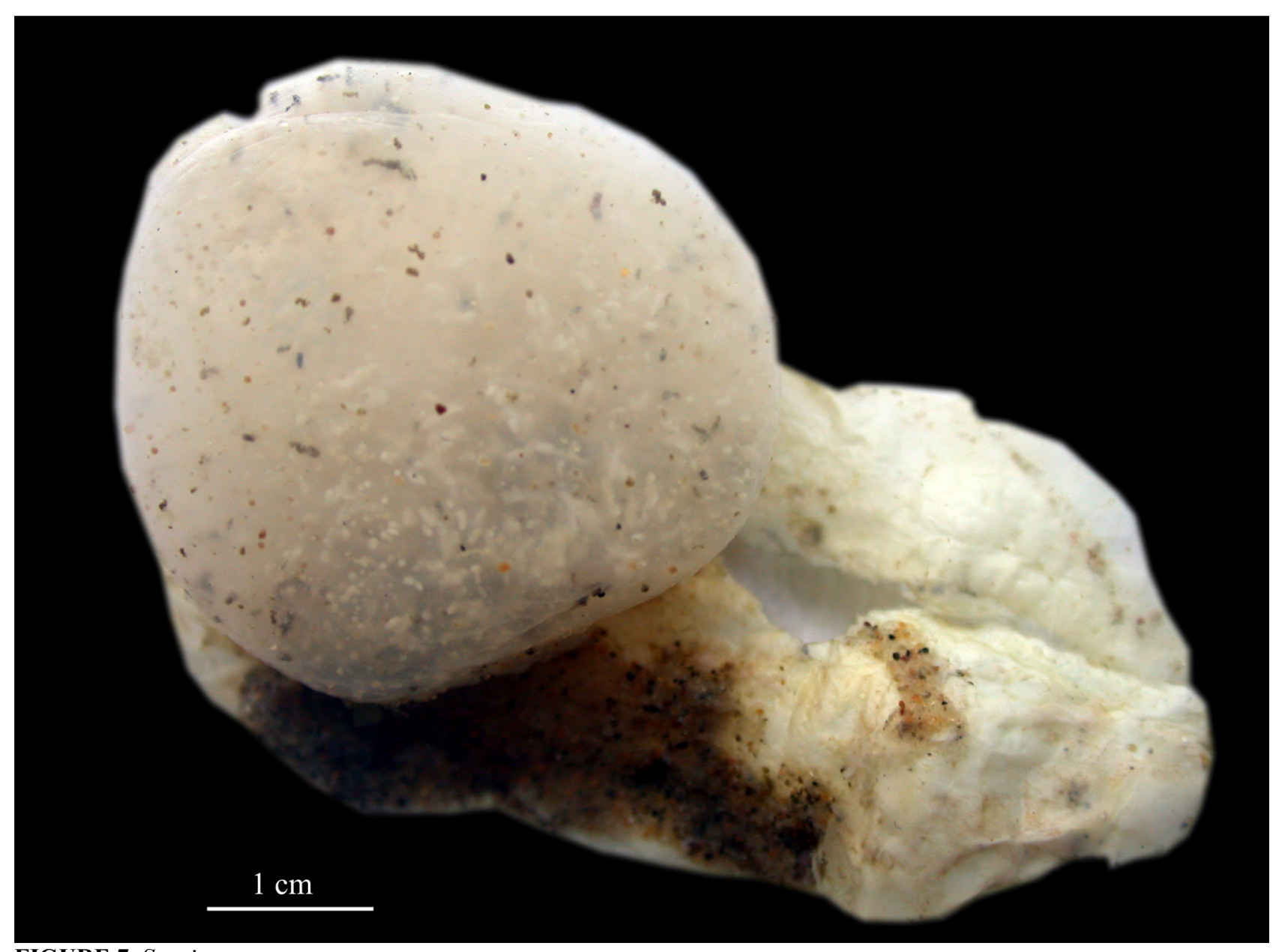

FIGURE 7. Synoicum $\mathrm{sp.}$

\section{Family DIDEMNIDAE Giard, 1872}

\section{Genus Polysyncraton Nott, 1892}

\section{Polysyncraton trivolutum (Millar, 1960)}

References: Didemnum trivolutum Millar 1960: 58-60, fig. 12 A-B.

Polysyncraton trivolutum Monniot \& Monniot 1983: 43-46, fig. 8 A-H, pl. IV A-D (synonymy); Monniot \& Monniot 1994: 18; Tatián et al. 2005: 209; Monniot et al. 2011: 10, fig. 3.

Material examined: several colonies adhered to the tunic of Ascidia meridionalis; trawl; -37.9876 lat. -54.6906 long. (station 8); $854 \mathrm{~m} ; 11$ August 2012 - three colonies adhered to corals; trawl; -37.9530 lat. -55.1843 long. (station 2); $291 \mathrm{~m} ; 10$ August 2012 - one colony on one fragment of coral; trawl; -37.9651 lat. -54.5320 long. (station 10); $1144 \mathrm{~m} ; 11$ August 2012 (Figures 8A-D).

Colonies configure flat and encrusting white patches on the tunics of $A$. meridionalis, debris and corals (Fig. 8A). The most superficial layer shows the greatest amount of spicules, which are specially concentrated around the oral apertures (Fig. 8B). Distributed unevenly and attached to the substrate, numerous yellow and spherical eggs (approximately $0.9 \mathrm{~mm}$ in diameter) were found (Fig. 8C).

The zooids show an average length of $1.8 \mathrm{~mm}$. Thorax and abdomen have the same size. The atrial languet is short and triangular. There is no muscular appendage. The thorax is separated from the abdomen by a thin and short neck. The stomach is rounded, almost spherical, and smooth-walled. The gonads, both male and female, are situated inside the intestinal loop. The number of male follicles ranges from three to four. They are densely packed in pear-shaped lobes. The vas deferens makes three to four spiral turns around them (Fig. 8D). In some zooids only the ovary is developed. 
Remarks. On the revision of the colonies described by Millar (1960) as Didemnum trivolutum from the Argentine Sea (Malvinas/Falkland Islands and Patagonian shelf), Monniot \& Monniot (1983) concluded that these specimens corresponded to the genus Polysyncraton based on: (1) the presence of one pointed atrial languet and (2) the morphology of the testes. Polysyncraton trivulutum is an eurybathic species, widely distributed in Antarctic and Sub-Antarctic waters up to the Patagonian shelf (Argentine Sea). The present is the northernmost record of the species. It is also the first record of the species below $935 \mathrm{~m}$ (Kott 1969).
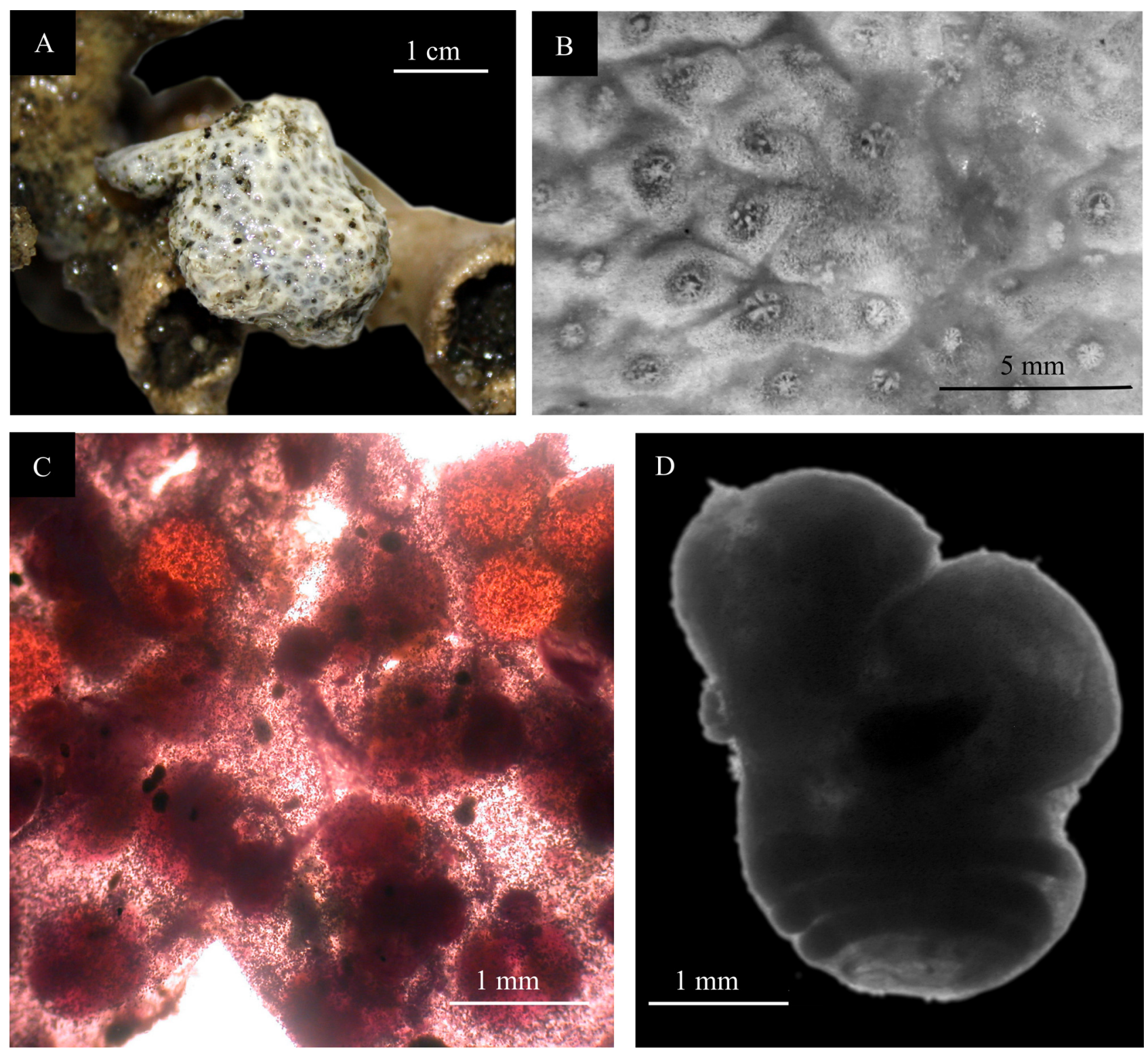

FIGURE 8. Polysyncraton trivolutum (Millar, 1960). A: colony; B: detail of oral apertures packed with spicules; C: surface of colony showing zooids (pink colored) and oval eggs. (orange colored); D: zooid with detail of coiled vas deferens at its base.

\section{Family HOLOZOIDAE Berrill, 1950}

\section{Genus Sycozoa Lesson, 1832}

\section{Sycozoa umbellata (Michaelsen, 1898)}

References: Colella umbellata Michaelsen 1898: 371;

Sycozoa umbellata Sluiter 1919: 12; Van Name 1945: 154, fig. 75 A-C (synonymy). 
Material examined: several colonies; net; -36.5433 lat. -53.3833 long. (station 5); 647 m; 10 August 2012 (Figures 9A-B).

Colonies consist of small heads supported by long, thin and frequently ramified stalks (Fig. 9A). On average, the heads measure $5.3 \mathrm{~mm}$ in length and $4.2 \mathrm{~mm}$ wide and are shaped in the form of ovoid masses. The stalks are smooth and extremely long. The average length of the stalks is $14 \mathrm{~cm}$. Each stalk supports from one to three heads, though the most frequent configuration consists of colonies with two heads. The tunic is yellowish and transparent when alive. After conservation in formalin, it acquires a more opaque tone. Its consistency is soft in the heads and coarse in the stalks.

Each head bears longitudinal rows of three to five zooids arranged in oblique or random-like configurations (Fig. 9B). On average, zooids are $1.9 \mathrm{~mm}$ in length. No larvae were found.
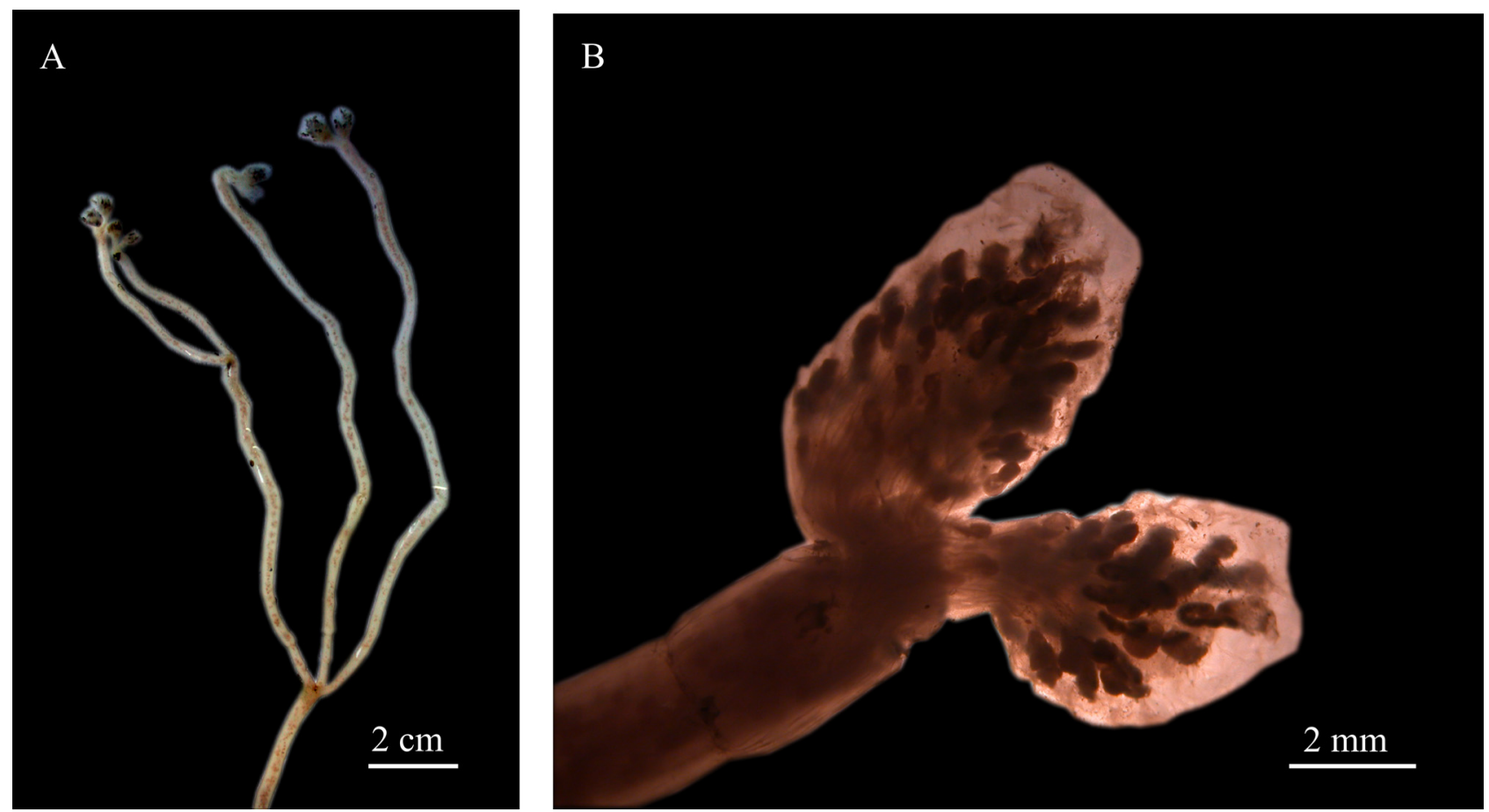

FIGURE 9. Sycozoa umbellata (Michaelsen, 1898). A: colony; B: heads with zooids.

TABLE 3. Differences among Sycozoa umbellata, Sycozoa georgiana, Sycozoa sigillinoides and Sycozoa gaimardi.

\begin{tabular}{|c|c|c|c|c|}
\hline Characteristic & S. umbellata & S. georgiana & S. sigillinoides & S. gaimardi \\
\hline Morphology of heads & Ovoid & Pear-shaped & Cylindrical & Dome-shaped \\
\hline $\begin{array}{l}\text { Number of heads on top of } \\
\text { each stalk }\end{array}$ & One to three, usually two & A single head & $\begin{array}{l}\text { One to two, usually } \\
\text { one }\end{array}$ & A single head \\
\hline $\begin{array}{l}\text { Thickness and length of } \\
\text { stalks }\end{array}$ & $\begin{array}{l}\text { Long (may reach } 14 \mathrm{~cm} \\
\text { in length) and slender }\end{array}$ & $\begin{array}{l}\text { Short (usually three } \\
\mathrm{cm} \text { ) and slender }\end{array}$ & $\begin{array}{l}\text { Variable lengths and } \\
\text { thicknesses }\end{array}$ & $\begin{array}{l}\text { Short (usually } 2.5 \\
\mathrm{~cm} \text { ) and slender }\end{array}$ \\
\hline Branching of the stalk & Branched & Not branched & Usually not branched & Not branched \\
\hline Distribution & $\begin{array}{l}\text { SE Pacific, SW Atlantic, } \\
\text { South Georgia Is. }\end{array}$ & South Georgia Is. & $\begin{array}{l}\text { Sub-Antarctic, } \\
\text { circumpolar }\end{array}$ & SW Atlantic \\
\hline
\end{tabular}

Remarks. The general shape of the colonies (small rounded heads supported by fine peduncles arising from a basal mass of stolons) resembles the closely related species Sycozoa georgiana (Michaelsen, 1907). According to Van Name (1945), each head of S. georgiana is "supported on a separate peduncle that can reach $3 \mathrm{~cm}$ in length, but is usually much shorter" (154 p.). The peduncles of the present specimen, on the contrary, reach $14 \mathrm{~cm}$ in length, have ramifications and usually have two heads. On the other hand, S. georgiana is cited exclusively for the South Georgia Islands. Sycozoa umbellata, in addition to the South Georgia Islands, has also been recorded in the SW Atlantic, near the area where the colonies of the present work were collected. 
Van Name (1945) also notes that $S$. umbellata is closely related to $S$. sigillinoides Lesson, 1930, of which it is distinguished by "the usual reproduction of numerous heads of the upper part of the peduncle or of broken or injured places along its length, and also fragments of peduncles" (154 p.). In addition, the length of the heads and consequently, the number of zooids per head in S. sigillinoides, is greater.

The only reliable characters to distinguish among these three species and Sycozoa gaimardi (Herdman, 1886), all with overlapping distribution ranges, are external: the appearance of the colony and the shape and size of the heads. Table 3 lists such differences in detail.

This is the deepest and northernmost record for the species.

\section{Order PHLEBOBRANCHIA Lahille, 1886}

\section{Family ASCIDIIDAE Herdman, 1882}

\section{Genus Ascidia Linnaeus, 1767}

\section{Ascidia meridionalis Herdman, 1880}

References: Ascidia meridionalis Herdman 1880: 465; Monniot et al. 2011: 22 (synonymy).

Material examined: One individual; trawl; -37.9951 lat. -54.6975 long. (station 7); $852 \mathrm{~m}$; 11 August 2012-Six individuals; trawl; -37.9876 lat. -54.6906 long. (station 8); $854 \mathrm{~m} ; 11$ August 2012-Six individuals; trawl; 38.0083 lat. -54.4178 long. (station 11); $1200 \mathrm{~m} ; 12$ August 2012-Two individuals; net; -37.9548 lat. -54.3909 long. (station 12); $1308 \mathrm{~m} ; 12$ August 2012 (Figures 10A-C).

The specimens are oval in shape and measure 2.5 to $12.2 \mathrm{~cm}$ in length (Fig. 10A). A single row of 28 to 54 filiform and simple oral tentacles are placed in alternated sizes on a wide oral velum (Fig. 10B). A small dorsal tubercle opens in a wide $\mathrm{U}$ or $\mathrm{V}$, with slightly rolled horns. The branchial sac extends down to the body end, covering the entire digestive system. A specimen (nine $\mathrm{cm}$ in length) presented 70 longitudinal vessels on its right side and 60 on its left side. The stigmata range from five to ten per mesh. There are crooked branchial papillae at the intersection of every longitudinal and transverse vessel. Intermediate simple papillae are very frequent although not constant (Fig. 10C). The border of the anus is simple and ends at the level of the top of the primary intestinal loop. The gonads and ramified gonoducts lie on top of the digestive system.

Remarks. Ascidia meridionalis resembles the closely allied species A. challengeri Herdman, 1882. Both share the same general aspect and are distributed in the Sub-Antarctic and Antarctic regions. Monniot \& Monniot (1983) and Monniot et al. (2011) give a list of reliable characters to distinguish between the two species. The examination of the collected specimens proceeding from an area very close to the type locality allowed us to update those characters. We strongly discourage the use of the presence of intermediate branchial papillae and the number of oral tentacles, since both characters showed intermediate values. Instead, we recommend the use of a set of particular differences which are resumed in Table 4.

This is the first register of the species below $1097 \mathrm{~m}$ (Herdman 1880).

TABLE 4. Reliable characters to distinguish between Ascidia meridionalis and Ascidia challengeri

\begin{tabular}{lll}
\hline Characters & A. meridionalis & A. challengeri \\
\hline Tunic & No papillae & Papillae on both apertures \\
Oral tentacles & Distributed along a single ring & Distributed along two rings \\
$\begin{array}{l}\text { Dorsal tubercle } \\
\text { Dorsal lamina }\end{array}$ & Far from neural ganglion & Close to neural ganglion \\
Branchial sac & Extends far beyond esophagus entrance & Does not overpass esophagus entrance \\
Position of the anus & At the level of the secondary intestinal loop & Far above the level of the secondary intestinal loop \\
\hline
\end{tabular}



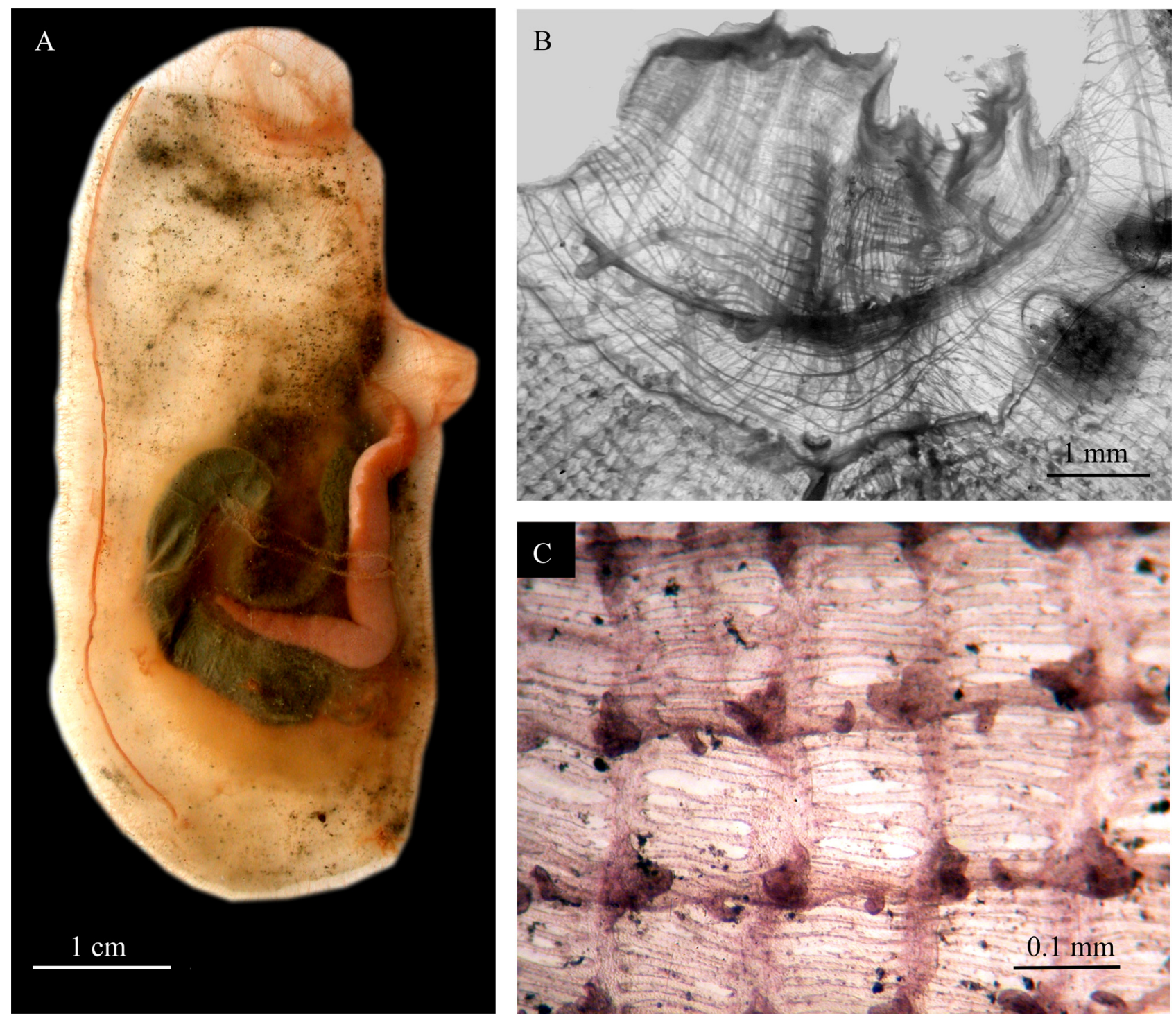

FIGURE 10. Ascidia meridionalis Herdman, 1880. A: individual without tunic; B: oral tentacles, dorsal tubercle and prepharyngeal band; C: detail of branchial sac: stigmata and papillae.

\section{Order STOLIDOBRANCHIA Lahille, 1886}

\section{Family STYELIDAE Sluiter, 1895}

\section{Genus Cnemidocarpa Huntsman, 1907}

\section{Cnemidocarpa drygalskii (Hartmeyer, 1911) Nomen conservandum}

References: Styela convexa Herdman 1881: 69.

Cnemidocarpa drygalskii Monniot \& Monniot 1983: 69, fig. 13C, D (synonymy); Sanamyan \& Sanamyan 1999: 1850; 2002: 341; Monniot et al. 2011: 29.

Material examined: One individual; trawl; -38.0083 lat. -54.4178 long. (station 11); $1200 \mathrm{~m} ; 12$ August 2012 (Figures 11A-C).

One individual $4.3 \mathrm{~cm}$ long and $2.4 \mathrm{~cm}$ wide was found attached to a piece of coral by its posterior margin. The tunic is wrinkled and tough, covered completely by fine translucent short hairs. When alive, the tunic is bright yellow. After conservation in formalin, it becomes duller and opaque, though it retains the yellowish hue (Fig. 
11A). Both apertures present thin orange rings at their outermost margins. 30 thin oral tentacles of two sizes are placed alternately in a single row (Fig. 11B). A wide velum with an undulated margin covers them completely, reaching the oral aperture. A small $\mathrm{U}$-shaped dorsal tubercle is placed at the bottom of a deep $\mathrm{V}$ formed by the prepharyngeal band. The dorsal lamina is a continuous and plain membrane with an undulated margin. The muscle fibers on the right side are thick and ramified (Fig. 11C). The muscle fibers on the left side are thin and distributed in longitudinal rows. There are four branchial folds on each side; the most dorsal one being the thickest. The branchial formula on the right side is:

\section{E-7-9-10-10-11-10-13-12-13-DL.}

There are four elongated and simple stigmata per mesh. Fine parastigmatic vessels are also present. The stomach is elongated transversally. It presents eight folds on each side. The gut loop does not overpass the level of the endostyle. The border of the anus is simple. There is a wide cloacal velum covering completely the atrial aperture. The circumference from where the velum arises presents a series of tiny simple cloacal tentacles. There is one elongated and sinuous gonad on each side. The testis follicles lie beneath the ovaries. The vas deferens and gonoduct are long, almost reaching the base of the atrial opening. The numerous endocarps cover the half ventral side of the body and are located around the gonads and inside the gut loop.

Remarks. Monniot C. (1978) and Monniot \& Monniot (1983) showed the variability among the individuals of C. drygalskii. The present specimen from the Argentine Sea shows intermediate features in relation to specimens described from Kerguelen, Crozet and Antarctica (Table 5). However, it presents additional characteristics not cited for any previous descriptions, reaffirming the high variability of the species:

The musculature on the right side is thick with a ramified pattern. The musculature on the left side is thin and mainly longitudinal;

The longitudinal vessels are far less numerous, never exceeding 12 bars per fold;

The margin of the oral velum presents a bubble-like texture.

This is the first record of the species in the SW Atlantic Ocean. It is also the northernmost register outside Antarctic waters, increasing its known range of distribution.
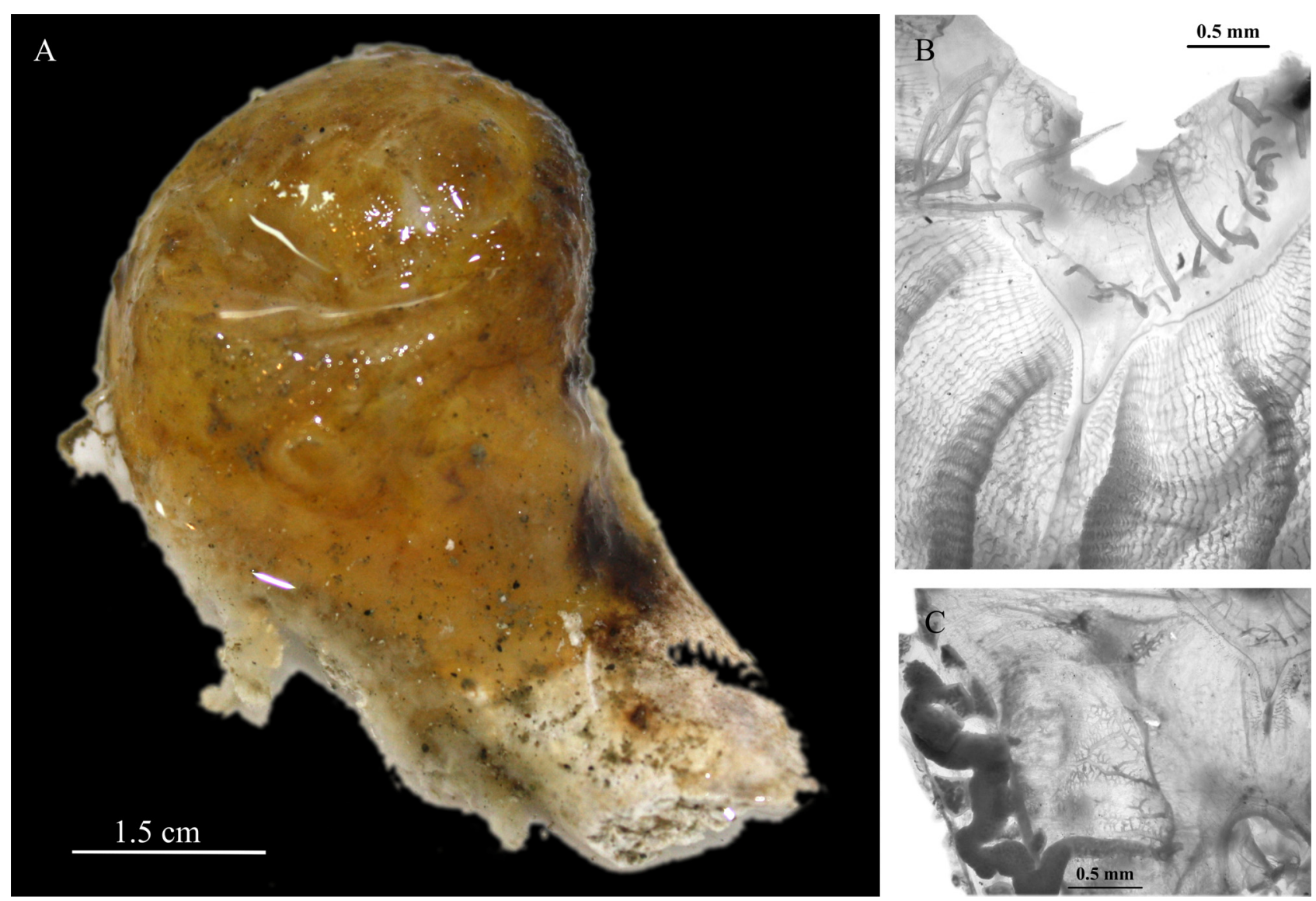

FIGURE 11. Cnemidocarpa drygalskii (Hartmeyer, 1911). A: individual; B: oral tentacles, dorsal tubercle, pre-pharyngeal band and branchial sac (part); C: detail of musculature (right side). 
TABLE 5. Differences among specimens of Cnemidocarpa drygalskii from four different geographic areas.

\begin{tabular}{llll}
\hline $\begin{array}{l}\text { Ross Sea and Antarctic } \\
\text { Peninsula }\end{array}$ & Crozet Island & Kerguelen Island & Argentine Basin \\
\hline $\begin{array}{l}\text { Dorsal lamina serrated or } \\
\text { undulated }\end{array}$ & Dorsal lamina undulated & Dorsal lamina undulated & Dorsal lamina undulated \\
$\begin{array}{l}\text { Two to five stigmata per } \\
\text { mesh }\end{array}$ & Four to five stigmata per mesh & $\begin{array}{l}\text { Four to five stigmata per } \\
\text { mesh }\end{array}$ & Four to five stigmata per mesh \\
$\begin{array}{l}\text { Eight to 24 longitudinal } \\
\text { vessels per fold }\end{array}$ & $\begin{array}{l}\text { Nine to } 28 \text { longitudinal vessels } \\
\text { per fold }\end{array}$ & $\begin{array}{l}\text { Nine to 28 longitudinal } \\
\text { vessels per fold }\end{array}$ & $\begin{array}{l}\text { Eight to 12 longitudinal } \\
\text { vessels per fold }\end{array}$ \\
$\begin{array}{l}\text { Border of anus simple or } \\
\text { lobed }\end{array}$ & Border of anus lobed & Border of anus simple & Border of anus simple \\
$\begin{array}{l}\text { Cloacal tentacles on cloacal } \\
\text { velum }\end{array}$ & $\begin{array}{l}\text { Cloacal tentacles on border of } \\
\text { cloacal velum }\end{array}$ & $\begin{array}{l}\text { Cloacal tentacles on cloacal } \\
\text { velum }\end{array}$ & $\begin{array}{l}\text { Cloacal tentacles on border of } \\
\text { cloacal velum }\end{array}$ \\
\hline
\end{tabular}

\section{Genus Styela Fleming, 1822}

\section{Styela squamosa Herdman, 1881}

References and synonymy: Styela squamosa Herdman 1881: 66; Sanamyan \& Sanamyan 2006: 321, figs. 7-9 (synonymy); 2012: 67, fig. 3 .

Material examined: One individual; trawl; -37.9651 lat. -54.5320 long. (station 10); 1144 m; 11 August 2012 (Figure 12).

The specimen measures $1.9 \mathrm{~cm}$ high and $1.2 \mathrm{~cm}$ wide. It was found completely covered by a thick and tough layer of sediment, with rests of sand and pebbles (Fig. 12). There are 18 oral tentacles disposed on the margin of an oral velum. The muscle fibers are densely packed and equally distributed on both sides. The branchial sac has four well developed folds on each side. Thin parastigmatic vessels are present. The stomach presents 24 well-marked folds and bears a small straight pyloric caecum. The border of the anus is triangular and ends near the atrial opening. There is one sinuously curved gonad on each side. The ovary is long and narrow. The small testicular follicles are placed around the distal part of each ovary. Numerous endocarps are distributed on both sides of the body.

Remarks. Styela squamosa has been described from most ocean basins in the world, except from the North Atlantic and Indian Oceans, at depths ranging from 165 to $5000 \mathrm{~m}$. This data permits to classify S. squamosa as an eurybathic and cosmopolitan deep-sea species (Monniot C. 1993). There is, though, some degree of character variation that falls into the range of standard intra-specific variability. Our specimen encountered off La Plata River (SW Atlantic), is closest to the description made by Sanamyan (1992) of a few individuals from the Sea of Okhotsk (NW Pacific) in relation to the shape of the border of the anus. While previous descriptions state that the border of the anus is bilobed, Sanamyan's specimens as well as ours, present a triangular border. The only difference between our specimen and all the rest resides in the number of oral tentacles: 18 in ours and around 30 in the rest.

\section{Family PYURIDAE Hartmeyer, 1908}

\section{Genus Pyura Molina, 1782}

\section{Pyura pilosa Monniot C. \& Monniot F., 1974}

References: Pyura pilosa Monniot C. \& Monniot F. 1974: 97; 1983: 97 (synonymy); Sanamyan \& Sanamyan 1999: 1861, fig. 19.

Material examined: Two individuals; trawl; -38.0083 lat. -54.4178 long. (station 11); 1200 m; 12 August 2012. 


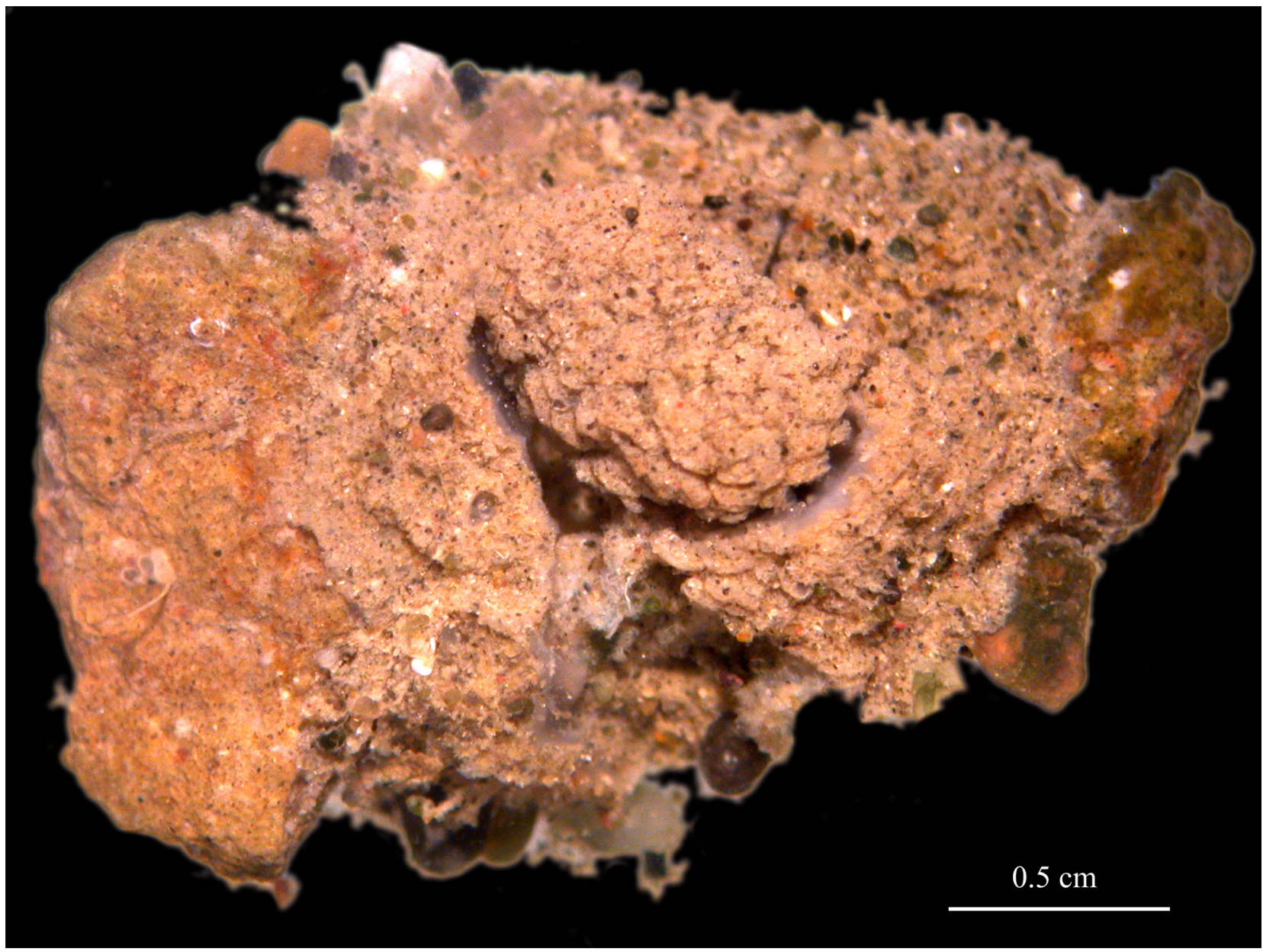

FIGURE 12. Styela squamosa Herdman, 1881: dorsal view.

The specimens are rounded and flattened dorso-ventrally. They measure two and $2.5 \mathrm{~cm}$ in diameter. Both were strongly attached to the substratum, adhered by the left side of the body. The tunic is delicate, transparent and thin, but it is completely covered by a thick layer of grains of sand and a few foraminifera. The mantle is yellowish and remarkably thick. The atrial and oral apertures are inconspicuous; both placed at the level of the border of the tunic. Both apertures are four-lobed. There are from 13 to 21 oral tentacles distributed on a single ring. They are filiform but stout and have small branches of the first order. There is a wide velum with undulated margins that extends from the base of the oral tentacles to the base of the oral aperture. The dorsal tubercle is small. It was Vshaped in one specimen and oval-shaped in the other. The pre-pharyngeal band could only be distinguished in the smaller specimen. It forms a deep dorsal $\mathrm{V}$ surrounding the dorsal tubercle. The dorsal lamina is divided into approximately 28 equally short pointed languets. Thick musculature covers the totality of the body. Closely packed circular bands surround both apertures and extend almost to the base of the animal. The longitudinal fibers are more separately distributed. They radiate from the apertures and reach the mid-ventral line of the body. The branchial sac has six folds on each side. There are around six to eight rectangular stigmata per mesh. The branchial formula on the right side corresponding to the smallest specimen is:

\section{E-4-7-1-9-2-11-2-14-2-11-2-10-0-DL}

The smooth-walled stomach is small and elongated transversely. It is completely covered by several branched hepatic lobes. The primary loop of the gut is widely open. The border of the anus is smooth. There is one gonad on each side. They consist of approximately 11 sac-like testicular follicles aligned on both sides of a central tubular ovary. The oocytes are big and spherical; almost the same size as each individual testicular sac. No endocarps are present.

Remarks. This is the deepest record of the species, increasing its bathymetric range in $600 \mathrm{~m}$. This is also the northernmost record of the species in the SW Atlantic Ocean, increasing its known range of distribution which also includes the South Western Pacific and Southern Indian Oceans. 
Family MOLGULIDAE Lacaze-Duthiers, 1877

\section{Genus Molgula Forbes, 1848}

\section{Molgula pyriformis Herdman, 1881}

References: Molgula pyriformis Herdman 1881: 236; Herdman 1882: 79: pl. 6, fig. 1-3; Monniot \& Monniot 1976: 652-655, fig. 11-12; Monniot \& Monniot 1983: 101 (part).

not Molgula malvinensis Ärnbäck-Christie-Linde, 1938: 5, pl. 1, fig. 1-3; Millar, 1960: 132, fig. 57; Kott, $1969: 149$ (part); Millar, 1970: 140; Monniot \& Monniot, 1983: 101.

Material examined: Seven individuals; net; -37.9951 lat. -54.6975 long. (station 7); $852 \mathrm{~m} ; 11$ August 2012Two individuals; trawl; -37.9876 lat. -54.6906 long. (station 8); 854 m; 11 August 2012-Four individuals; trawl; 37.9651 lat. -54.5320 long. (station 10); $1144 \mathrm{~m} ; 11$ August 2012-Two individuals; net; -38.0164 lat. -54.5054 long. (station 9); $1006 \mathrm{~m} ; 11$ August 2012 (Figures 13A-B).
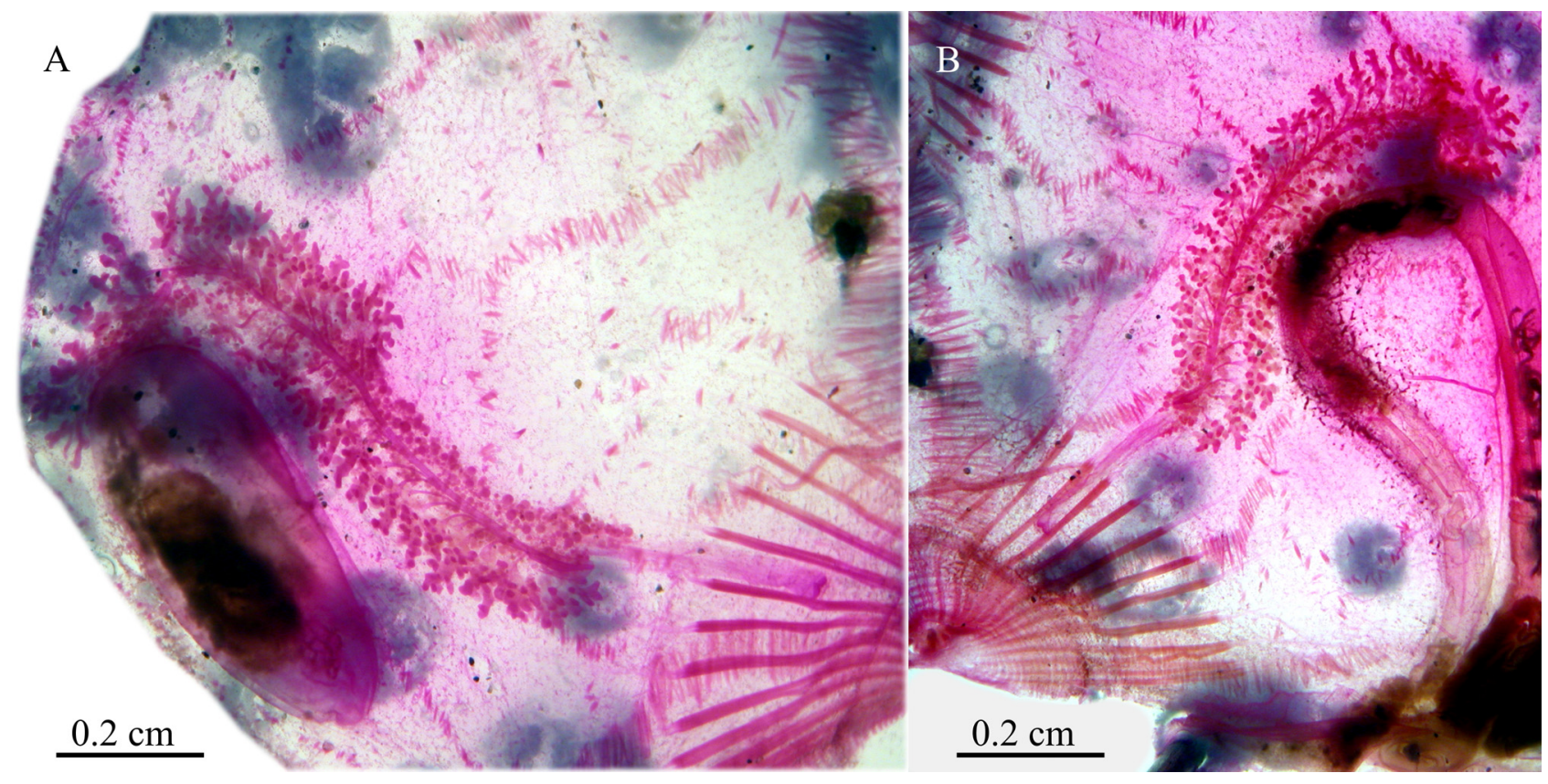

FIGURE 13. Molgula pyriformis Herdman, 1881. A: right gonad; B: left gonad.

Individuals are spherical, olive-shaped. The mean size of the specimens was $1.2 \mathrm{~cm}$ long by $1.5 \mathrm{~cm}$ wide, and the oral and atrial apertures were separated approximately $0.9 \mathrm{~cm}$ from each other. The tunic is completely embedded with rests of sand and fragments of algae and sea shells. Thin and evenly distributed hair-like processes also cover the totality of the body. Once all the external material is removed, the tunic appears delicate and transparent. The oral and atrial apertures have six pointed lobes. There is a short oral velum that may be smooth or bear small papillae. Seven two-sized oral tentacles of the third order are placed in a single circle alternately with numerous minute ones. One of the bigger tentacles is situated exactly in the mid-dorsal line. The slightly undulated pre-pharyngeal band lies away from the tentacular circle. It forms a deep V that surrounds the dorsal tubercle and part of the neural ganglion. The dorsal tubercle is "funnel-shaped" (Herdman 1881). The broad dorsal lamina has smooth margins and extends until the entrance of the esophagus. The musculature is composed of a series of strong longitudinal fibers that radiate from both apertures and extend until the mid-ventral side of the body (from 24 to 27 per aperture), two dorsal muscular bands that enclose the neural complex, thin and densely packed circular muscles, and a series of short latero-dorsal fascicles unevenly distributed. The branchial sac bears seven folds on the right side and six on the left. The stigmata are long and curved, forming spirals at the top of the infundibula. The number of infundibula per fold ranges from seven to nine and may be single or double. The branchial formula on the right side of one of the biggest specimens is:

$$
\text { E-0-5-0-7-0-9-0-10-0-11-0-9-0-8-0-DL }
$$


The short esophagus connects with a stomach completely covered with liver lobes. The intestine is long. The primary intestinal loop forms an open curve, while the secondary loop forms a semicircle that runs adjacent to the stomach. The border of the anus is smooth. There are two elongated S-shaped gonads on each side of the body. The pear-shaped testes are distributed on the margins, while the ova reside in the center. They extend until the distal bend of the primary intestinal loop, never superpassing it (Figs 13A-B). The oviducts are thick and long, extending almost until the atrial aperture. The vas deferens, on the contrary, is short. There is a narrow atrial velum whose margins are smooth.

Remarks. Molgula pyriformis resembles the closely related species Molgula malvinensis Ärnbäck-ChristieLinde, 1938 and Molgula occidentalis Traustedt, 1883. According to Millar (1960), the main characteristics that separate them rely on the structure of the gonads, the shape of the intestinal loop and the dorsal tubercle opening. On the distinction between M. malvinensis and M. pyriformis, Monniot \& Monniot (1976) agreed, claiming that the fundamental difference was found on the structure of the gonads (with M. malvinensis presenting more male follicles on each gonad). However, on the revision of the species (Monniot \& Monniot 1983), the authors proposed instead the synonymy of M. malvinensis with M. pyriformis. Subsequent sampling in the SW Atlantic enabled us to reject the latter proposition and support the decision of maintaining both as separate species. Taverna (2013) found six individuals which were identified as M. malvinensis in an area close to its type location (Malvinas/Falkland Islands) and in a similar depth range $(65-128 \mathrm{~m})$. Additionally, all of our specimens present the characters mentioned by Millar (1960) as belonging to M. pyriformis. Our specimens were also found in an area close to the type locality of the latter (off Buenos Aires) and in a similar depth range (100-1097 m). In this way, we believe that the range of distribution of $M$. pyriformis is restricted to the north of the Argentine Sea, while the range of distribution of M. malvinensis extends from the south of the Argentine Sea to the north of the South Orkney Islands. Thus, the only specimen found in the Southern Ocean classified as M. pyriformis by Monniot \& Monniot, 1983, might belong to M. malvinensis.

\section{Molgula setigera Ärnbäck-Christie-Linde, 1938}

References: Molgula setigera Ärnbäck-Christie-Linde 1938: 7, fig. 2, pl. 1, fig. 4-8; Monniot \& Monniot 1983: 102-104, fig. 21 A-C, pl. VII D (synonymy).

Molgula setigera georgiana Millar, 1960: 134, fig. 58 A-D.

Molgula robini Monniot \& Monniot 1983: 104, pl. VII F (synonymy).

Molgula setigera marioni Millar, 1960: 136, fig. 58 E-G.

Molgula marioni Monniot \& Monniot, 1983: 54, fig. 21 D-E, pl. VII D-E.

Material examined: Six individuals; net; -37.9951 lat. -54.6975 long. (station 7); 852 m; 11 August 2012-Two individuals; trawl; -37.9651 lat. -54.5320 long. (station 10); $1144 \mathrm{~m} ; 11$ August 2012 (Figures 14A-D).

All specimens share the characteristic shape and aspect of the species: they are ovoid and flattened dorsoventrally. The tunic, completely covered by a dense layer of sand, presents sparsely distributed long bristle-like projections mainly confined to the area around both apertures. The bigger specimen measured $2.1 \mathrm{~cm}$ in diameter, while the smallest one only reached $0.8 \mathrm{~cm}$. There are from 16 to 20 oral tentacles of the third order placed in a single circle. The branchial sac has seven folds on each side, bearing from seven to 11 longitudinal vessels. No longitudinal vessels are found in between the folds. Irregular stigmata form approximately six infundibula along each fold. There is one sausage-like gonad on each side, dorsal to the gut loop and kidney. The ovaries concentrate in the center while the testes are distributed on the margins. Each gonad bears one long and wide oviduct that opens almost at the base of the atrial aperture. It can bend either dorsally or ventrally. The vas deferens is thin and long and also opens near the base of the atrial aperture, running parallel to and some distance away from the oviduct. The number of vas deferens found in our samples was extremely variable (Fig. 14A-D): there were two specimens with only one vas deferens on each side; two individuals with two vas deferens on each side; one with two vas deferens on the right side but one vas deferens on the left side; one specimen with only one vas deferens on the right side but two on the left side; one with four vas deferens on the right side and only one on the left side; and one individual with four vas deferens on the right side and three on the left side.

Remarks. Based on the descriptions made by Millar (1960) and the discussion by Kott (1969) about the morphotype, Monniot \& Monniot (1983) proposed the existence of three different species based on the 
characterization of the gonads: (1) Molgula setigera, with only one sperm-duct on each side and the oviduct bent dorsally; (2) Molgula robini Monniot C. \& Monniot F., 1983, with many sperm-ducts on both sides and the oviduct bent dorsally; and (3) Molgula marioni Millar, 1960, with only one sperm-duct on each side and the oviduct bent ventrally. The authors also state the correspondence of each species with a particular geographical area. However, our specimens showed a random combination of vas deferens on both sides of the body (Fig. 14A-D). In sight of this new data, we propose that both M. setigera and M. robini are no longer treated as separate species. Instead, we suggest them to be considered as synonyms.

We also found one individual with the oviducts bent ventrally (Fig. 14D). Monniot \& Monniot (1983), on the finding of specimens with the oviducts bent ventrally in the SW Atlantic, proposed a re-colonization of M. marioni from the Sub-Antarctic Region (Crozet, Kerguelen and Marion Islands) to the Magellanic area. However, our data do not support that view. As Kott (1969), we consider that the position of the oviduct does not stand as a valid character to differentiate among the mentioned species, but a result of intra-specific morphological variation.

We therefore propose the new synonymy: Molgula robini Monniot C. \& Monniot F., $1983=$ Molgula marioni Millar, $1960=$ Molgula setigera Ärnbäck-Christie-Linde, 1938. The number of sperm-ducts and direction of the oviduct can no longer be considered reliable characters to distinguish among them. The range of distribution of $M$. setigera is thus expanded, covering from off La Plata River (SW Atlantic) to the area around the South Georgia Islands (Southern Ocean) and the Sub-Antarctic Islands Crozet, Kerguelen and Marion.

This is the deepest record of the species, increasing its bathymetric register in $950 \mathrm{~m}$.
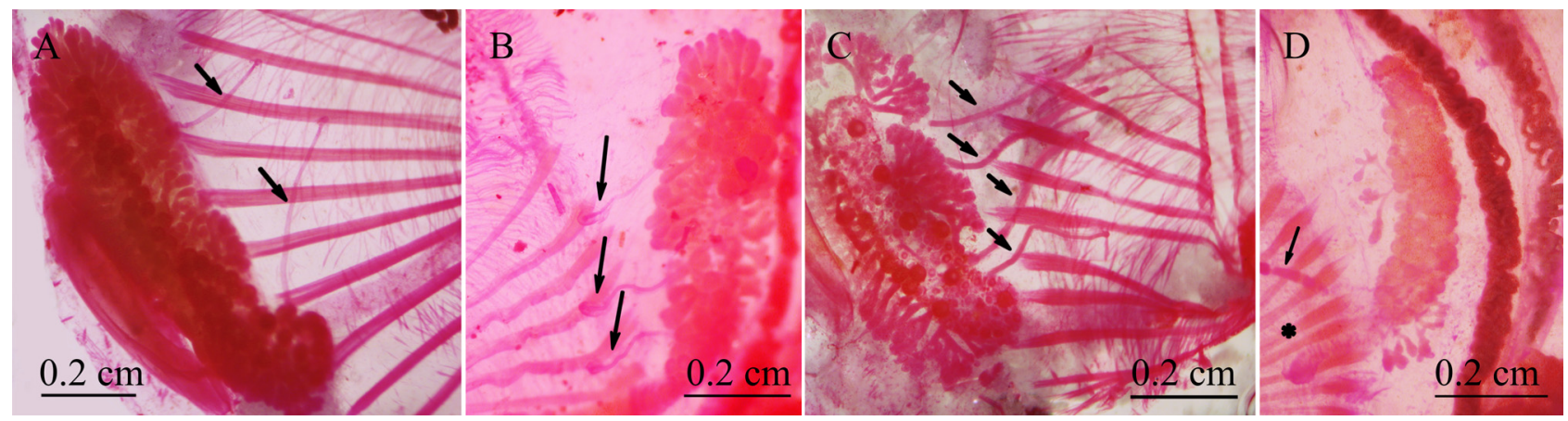

FIGURE 14. Molgula setigera Ärnbäck-Christie-Linde, 1938. A: right gonad with two vas deferens (arrows); B: left gonad with tree vas deferens (arrows); C: right gonad with four vas deferens (arrows); D: left gonad with one vas deferens (arrow) and oviduct bent ventrally $(*)$.

\section{Genus Asajirus Kott, 1989}

\section{Asajirus indicus (Oka, 1913)}

References: Hexacrobylus indicus Oka 1913: 6.

Asajirus indicus Kott 1989: 521-524, fig. 1; Sanamyan \& Sanamyan 2006: 339-342; fig. 19 (synonymy).

Material examined: 1 individual; trawl; -37.9651 lat. -54.5320 long. (station 10); $1144 \mathrm{~m}$; 11 August $2012-3$ individuals; net; -37.9448 lat. -54.1832 long. (station 13); $1508 \mathrm{~m}$; 13 August 2012-11 individuals; net; -37.8717 lat. -53.9572 long. (station 14); $1738 \mathrm{~m} ; 15$ August 2012 (Figures 15A-D).

Specimens are spherical, either ovoid or pyriform-shaped (Fig. 15A). The biggest specimen measured $2.8 \mathrm{~cm}$ long by $2.4 \mathrm{~cm}$ wide, while the smallest one was $0.8 \mathrm{~cm}$ long by $0.6 \mathrm{~cm}$ wide. The oral aperture is surrounded by six big and thick triangular lobes (which Kott 1989 denominated "branchial arms") with pinnate margins. Internally, these lobes acquire branches of the third order. The atrial aperture, located at approximately $1 / 5$ from the oral aperture, is inconspicuous. The short pharynx presents two circular perforations that connect with the lateral pharyngeal chambers which, in turn, open to the atrial cavity (Fig. 15B). The stomach occupies the totality of the ventral side (Fig. 15C). It is connected with a large and folded hepatic pouch lying above it through a short duct with a circular aperture. The sperm-ducts are also short and open directly into the atrial cavity (Fig. 15D).

Remarks. On the revision of the family Hexacrobylidae, Kott (1989) made Hexacrobylus indicus Oka, 1913 
the type species of the new genus Asajirus. Monniot \& Monniot (1990) described several species of this group under a new genus Hexadactylus (an objective synonym of Asajirus). Sanamyan \& Sanamyan (2006) discussed the features used by Monniot \& Monniot (1990) to distinguish among several species and concluded, as Kott 1989 did, that they could not justify specific separation. We agree with Kott (1989) in the recognition of only three species under Asajirus: Asajirus indicus (Oka, 1913), Asajirus dichotomus (Monniot C. \& Monniot F., 1984) and Asajirus gulosus (Monniot C. \& Monniot F., 1984). Based on morphological evidences Kott (1989) signaled the close relationship between Hexacrobylidae and Molgulidae. Phylogenetic studies based on 18S rDNA sequences confirmed that the former are in fact highly modified carnivorous Molgulidae (Tatián et al. 2011).
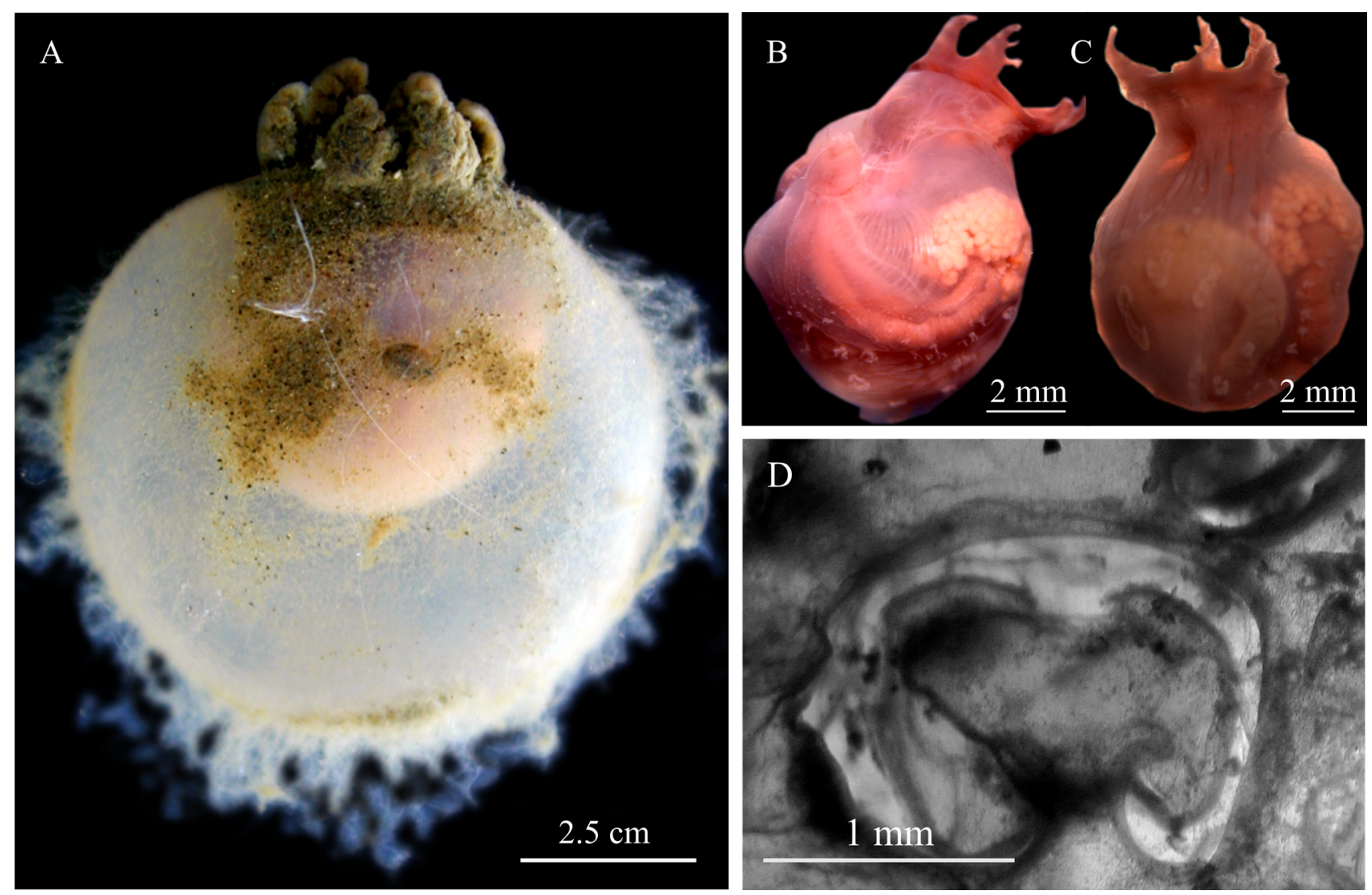

FIGURE 15. Asajirus indicus (Oka, 1913). A: individual with tunic; B: dorsal side with details of circular musculature, nervous system, atrial aperture and gonads (test removed); C: ventral side with detail of longitudinal muscles, stomach and gonads (test removed); D: ventral side of pharynx showing circular perforations.

\section{Acknowledgments}

We are especially grateful with an anonymous reviewer whose suggestions helped to improve the quality of this work. Special thanks to all scientists, students and A.R.A. crew involved in the Argentinean Slope Campaigns. We also want to acknowledge Coco Ferreyra for his contribution. This work was partially funded by Consejo Nacional de Investigaciones Científicas y Técnicas, CONICET (PIP CONICET N ${ }^{\circ}$ 20130100508), Secretaría de Ciencia y Tecnología, Universidad Nacional de Córdoba (SECyT-UNC 30720150100406CB), and IDEA WILD.

\section{References}

Ärnbäck-Christie-Linde, A. (1938) Ascidiacea. Part 2. Further zoological Results of the Swedish Antarctic Expedition, 3 (4), 154.

Brewin, B.I. (1950) Ascidians from Otago coastal waters. Transactions and Proceedings of the Royal Society of New Zealand, 78 (1), 54-63. 
Brewin, B.I. (1951) Ascidians of New Zealand. Part 6. Ascidians of the Hauraki Gulf. Part II. Transactions and Proceedings of the Royal Society of New Zealand, 79 (1), 104-113.

Brewin, B.I. (1952) Ascidians of New Zealand. Part 8. Ascidians of the East Cape Region. Transactions and Proceedings of the Royal Society of New Zealand, 80 (2), 187-195.

Carreto, J.I., Carignan, M.O., Montoya, N.G. \& Cucchi Colleoni, A.D. (2007) Ecología del fitoplancton en los sistemas frontales del Mar Argentino. El Mar Argentino y sus Recursos Pesqueros, 5, 11-31.

Cunningham, R.O. (1871) Notes on the reptiles, Amphibia, fishes, Mollusca, and Crustacea obtained during the voyage of H.M.S. Nassau in the years 1866-1869. Transactions of the Linnean Society of London, 27, 465-502.

https://doi.org/10.1111/j.1096-3642.1871.tb00219.x

Ebbe, B., Billet, D.S.M., Brandt, A., Ellingsen K., Glover, A., Keller, S., Malyutina, M., Martínez Arbizu, P., Molodtsova, T., Rex, M., Smith, C. \& Tselepides, A. (2010) Diversity of Abyssal Marine Life. In: McIntyre, D.A. (Ed.), Life in the Wolrd's Oceans: Diversity, Distribution, and Abundance. Wiley-Blackwell Publishing Ltd., Oxford, pp. 139-160.

https://doi.org/10.1002/9781444325508.ch8

Harant, H. \& Vernières, P. (1938) Ascidiae compositae. Australasian Antarctic Expedition 1911-1914. Scientific Report, SeriesC (Zoology and Botany), 3 (5), 1-13.

Hartmeyer, R. (1911) Die ascidien der deutschen Sudpolar-Expedition, 1901-1903. Deutsche Sudpolar-Expedition, 12, 403606.

Herdman, W.A. (1880) Preliminary report on the Tunicata of the Challenger Expedition. Part II. Proceedings of the Royal Society of Edinburgh, 10, 714-726.

https://doi.org/10.1017/S0370164600044606

Herdman, W.A. (1881) Preliminary report on the Tunicata of the Challenger Expedition. Part III. Cynthidae. Proceedings of the Royal Society of Edinburgh, 11 (3), 52-58.

Herdman, W.A. (1882) Report on the Tunicata collected during the Voyage of H.M.S. Challenger during the years 1873-76; Part I. Ascidiae simplices. Report of the Scientific Results of the Voyage of H.M.S. Challenger during the years 1873-76, 6 (17), 1-296.

Herdman, W.A. (1886) Report on the Tunicata collected during the Voyage of H.M.S. Challenger during the years $1873-76$. Part II. Ascidiae compositae. Report of the Scientific Results of the Voyage of H.M.S. Challenger during the years 187376, 14 (38), 1-399.

Hessler, R.R. \& Sanders, H.L. (1967) Faunal diversity in the deep-sea. Deep-Sea Research, 14, 66-78. https://doi.org/10.1016/0011-7471(67)90029-0

Grassle, J.F. (1991) Deep-sea benthic biodiversity. BioScience, 41 (7), 464-469. https://doi.org/10.2307/1311803

Kott, P. (1969) Antarctic Ascidiacea. Antarctic Research Series, 13, 1-239.

Kott, P. (1989) The family Hexacrobylidae Seeliger, 1906 (Ascidiacea, Tunicata). Memoirs of the Queensland Museum, 27 (2), 517-534.

Kott, P. (1990) The Australian Ascidiacea. Part 2. Aplousobranchia. Memoirs of the Queensland Museum, 29 (1), 1-266.

Kott, P. (1992) The Australian Ascidiacea. Part 3. Aplousobranchia (2). Memoirs of the Queensland Museum, 32 (2), $375-620$.

Lagger, C., Häussermann, V., Försterra, G. \& Tatián, M. (2009) Ascidians from the southern Chilean Comau Fjord (Chordata, Ascidiacea). Spixiana, 3 (2), 173-185.

Lagger, C. \& Tatián, M. (2013) Two new species of Distaplia (Tunicata: Ascidiacea) from the SW Atlantic, Argentina. Zootaxa, 3620 (2), 192-200. https://doi.org/10.11646/zootaxa.3620.1.10

Levin, L.A. \& Sibuet, M. (2012) Understanding Continental Margin Biodiversity: A New Imperative. Annual Review of Marine Science, 4, 79-112. https://doi.org/10.1146/annurev-marine-120709-142714

Loreau, M. (2007) Biodiversity and Ecosystem Functioning: The Mystery of the Deep Sea. Current Biology, 18 (3), $126-128$. https://doi.org/10.1016/j.cub.2007.11.060

Maggioni, T., Taverna, A. \& Tatián, M. (2016) Redescription of the deep-sea colonial ascidian Synoicum molle (Herdman, 1886): first record since its original finding during the Challenger Expedition. Zoosystematics and Evolution, 92 (2), 181185. https://doi.org/10.3897/zse.92.9521

Menot, L., Sibuet, M., Carney, R.S., Levin, L.A., Rowe, G.T., Billett, D.S.M., Poore, G., Kitazato, H., Vanreusel, A., Galeron, J., Lavrado, H.P., Sellanes, J., Ingole, B. \& Krylova, E.M. (2010) New perceptions of continental margin biodiversity. In: McIntyre A.D. (Ed.), Life in the World's Oceans: Diversity, Distribution, and Abundance. Wiley-Blackwell Publishing Ltd., Oxford, pp. 79-103. https://doi.org/10.1002/9781444325508.ch5

Michaelsen, W. (1898) Vorläufige Mitteilung über einige Tunicaten aus dem Magalhaensischen Gebeit sowie von Süd Geogien. Zoologischer Anzeiger, 21, 363-372.

Michaelsen, W. (1907) Tunicaten. Ergebnisse der Hamburger Magalhaensischen Sammedreise, 1892-1893, Hamburg, 1, 1-84.

Michaelsen, W. (1924) Ascidiae Krikobranchiae von Neuseeland, den Chatham und den Auckland Inslen. Videnskabelige Meddelelser fra Dansk Naturhistorisk Forening, 77, 263-434. 
Millar, R.H. (1960) Ascidiacea. Discovery Reports, 30, 1-160.

Millar, R.H. (1970) Ascidians, including specimens from the deep sea, collected by R.V. 'Vema' and now in the American Museum of Natural History. Zoological Journal of the Linnean Society, 49, 99-159. https://doi.org/10.1111/j.1096-3642.1970.tb00732.x

Monniot, C. (1978) Ascidies Phlébobranches et Stolidobranches du Sud de l'Océan Indien. Annales de l'Institute Océanographique, Paris, 54 (2), 171-224.

Monniot, C. (1993) Tunicata: sur trois espèces d'ascidies bathyales récoltées au cours de la campagne franco-indonésienne Karubar. In: Crosnier, A. (Ed.), Résultats des Campagnes Musorstom, 11, pp. 255-359.

Monniot, C. \& Gaill, F. (1978) Polyclinidae (Ascidiacea) du Sud-Ouest de l'Océan Indien. Annales de l'Institut Océanographique, Paris, 54 (2), 139-162.

Monniot, C. \& Monniot, F. (1974) Ascidies des Ils Kerguelen récoltées par P.M. Arnaud. Thetys, 5 (4), $715-734$.

Monniot, C. \& Monniot, F. (1978) Recent work on the deep-sea tunicates. Oceanography and Marine Biology: An annual review, 16, 181-228

Monniot, C. \& Monniot, F. (1983) Ascidies antarctiques et subantarctiques: Morphologie et Biogeographie. Mémoires du Muséum National d'Histoire Naturelle, Paris, 125, 1-168.

Monniot, C. \& Monniot, F. (1984) Nouvelles Sorberacea (Tunicata) profondes de l'Atlantique Sud et l'Ocean Indien. Cahiers de Biologie Marine, 25, 197-215.

Monniot, C. \& Monniot, F. (1985) Nouvelles récoltes de Tuniciers benthiques profonds dans l'océan Atlantique. Bulletin du Muséum National d'Histoire Naturelle, Paris, 4 Série 4, section A, 7 (1), 5-37.

Monniot, C. \& Monniot, F. (1990) Revision of the class Sorberacea (benthic tunicates) with descriptions of seven new species. Zoological Journal of the Linnean Society, 99 (3), 239-290. https://doi.org/10.1111/j.1096-3642.1990.tb00562.x

Monniot, C. \& Monniot, F. (1994) Ascidians collected in the Weddell Sea by the RV 'Polarstern' (EPOS cruise leg 3). Bulletin du Muséum National d'Histoire Naturelle, Paris, 16, 13-37.

Monniot, F. \& Monniot, C. (1976) Quelques ascidies bathyales et abyssales du Sud Est Atlantique. Bulletin du Muséum National d'Histoire Naturelle Zoologie, 387 (269), 671-680.

Monniot, F. (1978) Révision des Polyclinidae (Ascidiacea) des 1ere et 2eme expéditions antarctiques françaises décrites par C. $\mathrm{Ph}$. Sluiter. Bulletin du Muséum National d'Histoire Naturelle, Paris, 351, 3-18.

Monniot, F., Dettai, A., Eleaume, M., Cruaud, C. \& Ameziane N. (2011) Antarctic Ascidians (Tunicata) of the FrenchAustralian survey CEAMARC in Terre Adélie. Zootaxa, 2817, 1-54.

Muñoz, A., Cristobo, J., Rios, P., Druet, M., Polonio, V., Uchupi, E. \& Acosta, J. (2012) Sediment drifts and cold-water coral reefs in the Patagonian upper and middle continental slope. Marine and Petroleum Geology, 36 (1), $70-82$. https://doi.org/10.1016/j.marpetgeo.2012.05.008

Oka, A. (1913) Zur kenntnis der zwei aberranten Ascidien Gattungen Dicopia Sluit und Hexacrobylus Sluit. Zoologischer Anzeiger, 43, 1-10.

Piola, A.R. \& Rivas, A.L. (1997) Corrientes en la Plataforma Continental. El Mar Argentino y sus Recursos Pesqueros, 1, 119132.

Pereira Brandini, F., Boltovskoy, D., Piola, A., Kocmur, S., Röttgers, R., Abreu, P.C. \& Mandes Lopes, R. (2000) Multiannual trends in fronts and distribution of nutrients and chlorophyll in the southwestern Atlantic (30-62 $\left.{ }^{\circ} \mathrm{S}\right)$. Deep-Sea Research I, 47, 1015-1033. https://doi.org/10.1016/S0967-0637(99)00075-8

Priotto, S.E. (2017) Dinámica de compuestos nitrogenados en zonas productivas del Mar Argentino en relación con la producción de biomasa de crustáceos planctónicos. Tesis Doctoral, Universidad Nacional del Sur, Bahía Blanca, 175 pp.

Ramírez-Llodra, E. \& Billet, D.S.M. (2006) Ecosistemas de las profundidades marinas: reservorio privilegiado de la biodiversidad y desafíos tecnológicos. In: Duarte, C. (Ed.), La exploración de la diversidad marina. Desafíos científicos y tecnológicos. Fundación BBVA, España, pp. 65-94.

Ramírez-Llodra, E., Brandt, A., Danovaro, R., De Mol, B., Escobar, E., German, C.R., Levin, L.A., Martinez Arbizu, P., Menot, L., Buhl-Mortensen, P., Narayanaswamy, B.E., Smith, C.R., Tittensor, D.P., Tyler, P.A., Vanreusel, A. \& Vecchione, M. (2010) Deep, diverse and definitely different: unique attributes of the world's largest ecosystem. Biogeosciences, 7, 2851-2899. https://doi.org/10.5194/bg-7-2851-2010

Rex, M. (1981) Community Structure in the deep-sea benthos. Annual Review of Ecology and Systematic, 12, 331-353. https://doi.org/10.1146/annurev.es.12.110181.001555

Sanamyan, K.E. (1992) Ascidians from the sea of Okhotsk collected by R.V. "Novoulyanovsk". Ophelia, 36 (3), $187-194$. https://doi.org/10.1080/00785326.1992.10430369

Sanamyan, K.E. \& Sanamyan, N.P. (1999) Some benthic Tunicata from the southern Indo-Pacific Ocean. Journal of Natural History, 33, 1835-1876. https://doi.org/10.1080/002229399299761

Sanamyan, K.E. \& Sanamyan, N.P. (2002) Deep water ascidians from the south western Atlantic (RV Dimitri Mendeleev, cruise 43 and Academic Kurchatov, cruise 11). Journal of Natural History, 36, 305-359.

https://doi.org/10.1080/00222930010004232 
Sanamyan, K.E. \& Sanamyan, N.P. (2006) Deep-water ascidians (Tunicata: Ascidiacea) from the northern and western Pacific. Journal of Natural History, 40 (5-6), 307-344.

https://doi.org/10.1080/00222930600628416

Sanamyan, K.E. \& Sanamyan, N.P. (2012) Deep-water Ascidiacea from the Sea of Japan. Zootaxa, 3245, 63-68.

Sanamyan, K.E. \& Schories, D. (2003) Ascidians from the Strait of Magellan. Aqua, Journal of Ichtyology and Aquatic Biology, 7 (3), 89-96.

Sanders, H.L. (1968) Marine Benthic Diversity: A Comparative Study. The American Naturalist, 102 (925), $243-282$.

https://doi.org/10.1086/282541

Sluiter, C.P. (1900) Tunicaten aus dem Stillen Ozean. Zoologische Jahrbücher, 11, 1-64.

Sluiter, C.P. (1906) Tuniciers. In: Expédition Antarctique Française (1903-1905). Masson et Cie, Paris, pp. 1-48.

Sluiter, C.P. (1919) Über einige alte und neue Ascidien aus dem Zoologischen Museum von Amsterdam. Bijdragen tot de Dierkunde, 21 (1), 1-12.

Sluiter, C.P. (1932) Die von Dr. L. Kohl-Larsen gesammelten Ascidien von Süd-Georgien und der Stewart Insel. Senkenbergiana, 14, 1-19.

Tatián, M., Antacli, J.C. \& Sahade, R. (2005) Ascidians (Tunicata, Ascidiacea): species distribution along the Scotia Arc. Scientia Marina, 69 (2), 205-214. https://doi.org/10.3989/scimar.2005.69s2205

Tatián, M., Lagger, C., Demarchi, M. \& Mattoni, C. (2011) Molecular phylogeny endorses the relationship between carnivorous and filter-feeding tunicates (Tunicata, Ascidiacea). Zoologica Scripta, 40 (6), 603-612. https://doi.org/10.1111/j.1463-6409.2011.00493.x

Taverna, A. (2013) Riqueza de ascidias de la Plataforma de Tierra del Fuego, colectadas durante la campaña CONCACEN II del BO "Puerto Deseado". Tesis de grado, Universidad Nacional de Córdoba, Argentina, 60 pp.

Taverna, A., Lagger, C., Maggioni, T., Reyna, P., Lovrich, G. \& Tatián, M. (2018) Ascidian distribution provides new insights to help define biogeographic provinces in the South American Region. Polar Biology, 41 (6), 1123-1131. https://doi.org/10.1007/s00300-018-2272-y

Traustedt, M.P.A. (1883) Vestindiske Ascidiae Simplices, Anden Afdeling. Molgulidae og Cynthiadae. Videnskabelige Meddelelser fra Dansk Naturhistorisk Forening ann. 1882, 108-136.

Van Name, W.G. (1945) The North and South American ascidians. Bulletin of the American Museum of Natural History, 84, 1146.

Violante, R.A., Paterlini, C.M., Costa, I.P., Hernández-Molina, F.J., Segovia, L.M., Cavallotto, J.L., Marcolini, S., Bozzano, G., Laprida, C., García Chapori, N., Bickert, T. \& Spie $\beta$, V. (2010) Sismoestratigrafía y Evolución Geomorfológica del Talud Continental adyacente al Litoral del Este Bonaerense, Argentina. Latin American Journal of Sedimentology and Basin Analysis, 17 (1), 33-62.

Woolley, S.N.C., Titterson, D.P., Dunstan, P.K., Guillera-Arroita, G., Lahoz-Monfort, J.J., Brendan, A.W., Worm, B. \& O’Hara, T.D. (2016) Deep-sea diversity patterns are shaped by energy availability. Nature, 533 (7603), 393-396. https://doi.org/10.1038/nature17937 